\title{
Methane emission and consumption at a North Sea gas seep (Tommeliten area)
}

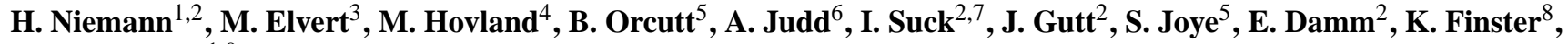 \\ and A. Boetius ${ }^{1,9}$ \\ ${ }^{1}$ Max Planck Institute for Marine Microbiology, 28359 Bremen, Germany \\ ${ }^{2}$ Alfred Wegener Institute for Polar and Marine Research, 27515 Bremerhaven, Germany \\ ${ }^{3}$ Research Center Ocean Margins, University of Bremen, 28359 Bremen, Germany \\ ${ }^{4}$ Statoil, 4001 Stavanger, Norway \\ ${ }^{5}$ University of Georgia, Athens, Georgia 30602-3636, USA \\ ${ }^{6}$ Wilderspool House, High Mickley, Stocksfield, Northumberland, NE43 7LU, UK \\ ${ }^{7}$ FILAX Gesellschaft für Wissenschaftliche Datenverarbeitung mbH, 27568 Bremerhaven, Germany \\ ${ }^{8}$ University of Aarhus, 8000 Aarhus, Denmark \\ ${ }^{9}$ International University Bremen, 28759 Bremen, Germany
}

Received: 1 August 2005 - Published in Biogeosciences Discussions: 30 August 2005

Revised: 26 October 2005 - Accepted: 11 November 2005 - Published: 24 November 2005

\begin{abstract}
The Tommeliten seepage area is part of the Greater Ekofisk area, which is situated above the Tommeliten Delta salt diapir in the central North Sea $\left(56^{\circ} 29.90^{\prime} \mathrm{N}\right.$, $2^{\circ} 59.80^{\prime} \mathrm{E}$, Norwegian Block 1/9, $75 \mathrm{~m}$ water depth). Here, cracks in a buried marl horizon allow methane to migrate into overlying clay-silt and sandy sediments. Hydroacoustic sediment echosounding showed several venting spots coinciding with the apex of marl domes where methane is released into the water column and potentially to the atmosphere. In the vicinity of the gas seeps, sea floor observations showed small mats of giant sulphide-oxidizing bacteria above patches of black sediments as well as carbonate crusts, which are exposed 10 to $50 \mathrm{~cm}$ above seafloor forming small reefs. These Methane-Derived Authigenic Carbonates (MDACs) contain ${ }^{13} \mathrm{C}$-depleted, archaeal lipids indicating previous gas seepage and AOM activity. High amounts of $s n 2$-hydroxyarchaeol relative to archaeol and low abundances of biphytanes in the crusts give evidence that ANaerobic MEthane-oxidising archaea (ANME) of the phylogenetic cluster ANME-2 were the potential mediators of Anaerobic Oxidation of Methane (AOM) at the time of carbonate formation. Small pieces of MDACs were also found subsurface at about $1.7 \mathrm{~m}$ sediment depth, associated with the AOM zone. This zone is characterized by elevated AOM and Sulphate Reduction (SR) rates, increased concentrations of ${ }^{13} \mathrm{C}$-depleted tetraether derived biphytanes, and specific bacterial Fatty Acids (FA). Further biomarker and 16S rDNA based analyses of this horizon give evidence that AOM is mediated by archaea belong-
\end{abstract}

Correspondence to: $\mathrm{H}$. Niemann

(hniemann@mpi-bremen.de) ing to the ANME-1b group and Sulphate Reducing Bacteria (SRB) most likely belonging to the Seep-SRB1 cluster. The zone of active methane consumption was restricted to a distinct horizon of about $20 \mathrm{~cm}$. Concentrations of ${ }^{13} \mathrm{C}$ -

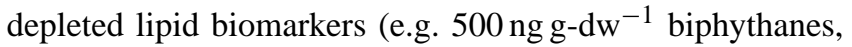
$140 \mathrm{ng} \mathrm{g}^{-\mathrm{dw}^{-1}}$ fatty acid ai- $\left.\mathrm{C}_{15: 0}\right)$, cell numbers $\left(1.5 \times 10^{8}\right.$ cells $\left.\mathrm{cm}^{-3}\right)$, AOM and SR rates $\left(3 \mathrm{nmol} \mathrm{cm}{ }^{-3} \mathrm{~d}^{-1}\right)$ in the Tommeliten AOM zone are 2-3 orders of magnitude lower compared to AOM zones of highly active deep water cold seeps such as Hydrate Ridge or the Gulf of Mexico.

\section{Introduction}

Upwelling of hydrocarbon-rich geofluids from subsurface reservoirs to the hydro- and atmosphere could be a relevant process with regard to emissions of the greenhouse gas methane. In temperate, shallow shelf seas, gas seepage is likely to contribute to methane emissions to the atmosphere, because of the seasonal deep mixing of the water column, which may intersect the gas plumes above active seeps. Whereas biogeochemical processes and related microorganisms reducing methane efflux have been studied at various cold seep systems in the deep sea and on the continental slope, very little knowledge on cold seeps situated on the continental shelf is available. As part of the OMARC cluster (Ocean Margin Deep-Water Research Consortium) of the 5th framework program of the European Commission, the project METROL (Methane flux control in ocean margin sediments) has been investigating methane fluxes from seep systems of the central and northern North Sea.

(C) 2005 Author(s). This work is licensed under a Creative Commons License. 


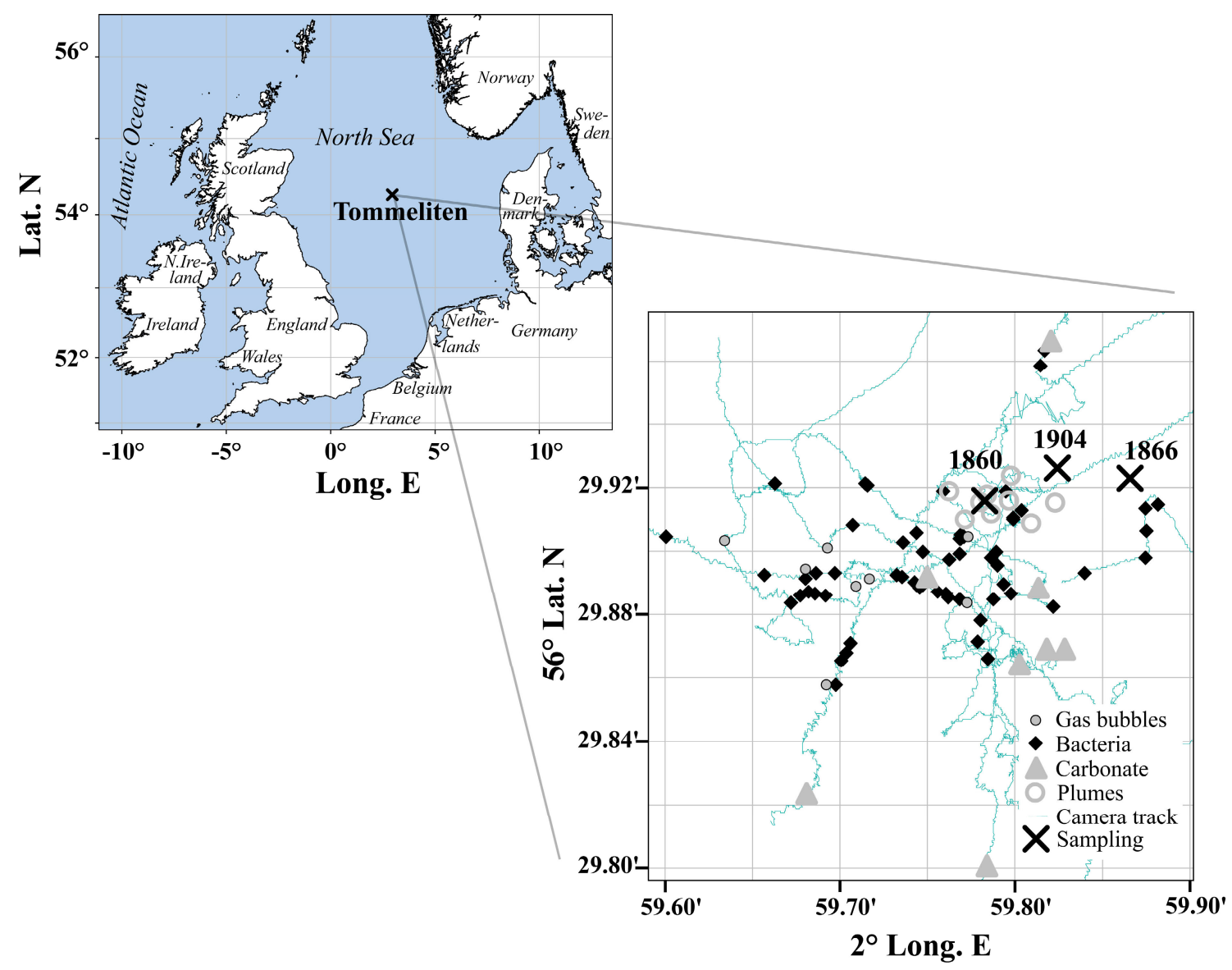

Fig. 1. A chart of the North Sea and the survey area at Tommeliten showing sampling positions of vibrocoring, sea floor and hydroacoustic observations.

Here we present results from biogeochemical and microbiological investigations of the Tommeliten seep area (Fig. 1; $56^{\circ} 29.90^{\prime} \mathrm{N}, 2^{\circ} 59.80^{\prime} \mathrm{E}$ ) in the central North Sea. This and other active cold seeps have been detected during pipeline route and site surveys by oil companies (Hovland and Sommerville, 1985; Hovland and Judd, 1988). Cold seeps have been reported from various geographic and geological settings (Judd, 2003). Once initiated, cold seeps may continuously emit gas, but they become inactive if subsurface gas and fluids are depleted, or undergo phases of dormancy where the shallow reservoir is recharged and none or little seepage occurs (Çifçi et al., 2003; Hovland and Judd, 1988). In the particular case of the central North Sea, thermogenic methane is produced in Jurassic sediments (Hovland and Judd, 1988). In the Tommeliten area, the enclosing sedimentary rocks have been pierced by a buried salt diapir, the so called Delta Structure, at about $1 \mathrm{~km}$ depth below sea floor (b.s.f.). As a result, the methane reservoir lacks a proper seal and disturbances on seismic profiles indicate that free gas migrates in sediments above the diapir to the sea floor (Hovland, 2002; Hovland and Judd, 1988). Previous expeditions to the Tommeliten seepage area with remotely operated vehi- cles (ROVs) documented streams of single methane bubbles of a thermogenic origin ( $-45.6 \%$ vs. Pee Dee Belemnite), small patches of filamentous, microbial mats and MDACs that outcrop on the sea floor (Hovland and Judd, 1988; Hovland and Sommerville, 1985; Thrasher et al., 1996). Such observations are typical for active seep systems, which have been found at passive and active continental margins.

High fluxes of methane usually lead to the development of methanotrophic microbial communities. Anaerobic methanotrophic archaea dominate submarine seep communities, because they profit from the abundance of sulphate, which is utilised as the electron acceptor for AOM (Hinrichs and Boetius, 2002; Reeburgh, 1996). High AOM activities lead to high fluxes of sulphide and the development of microbial mats of giant sulphide-oxidizing bacteria (e.g. Beggiatoa sp.) and other thiotrophic organisms (Boetius and Suess, 2004 and literature therein). Furthermore, methane venting at various cold seeps is associated with the precipitation of MDACs which often contain lipid biomarkers of AOM communities (Bohrmann et al., 1998; Diaz-del-Rio et al., 2003; Hovland et al., 1985, 1987; Michaelis et al., 2002; Peckmann et al., 1999; Roberts and Aharon, 1994; Thiel et al., 
2001). The phylogenetic origin of methanotrophic communities has been determined using combinations of lipid analysis and 16S rDNA methods in several methane seep environments (Boetius et al., 2000; Elvert et al., 1999; Hinrichs et al., 1999; Hoehler and Alperin, 1996; Knittel et al., 2003, 2005; Michaelis et al., 2002; Orphan et al., 2001b). Previous works identified two groups of ANME, which are phylogenetically related to methanogens (Methanosarcina sp.). Both ANME-1 and ANME-2 occur in consortia with relatives of a SRB cluster (Seep-SRB1) within the Desulfosarcina/Desulfococcus branch (Knittel et al., 2003). Although the geology and biology of a variety of shallow water cold seeps have been well investigated, there is still very little known on the biogeochemistry and relevance of microbial methane consumption (Barry et al., 1996, 1997; Bian et al., 2001; Bussmann et al., 1999; Dando and Hovland, 1992; Garcia-Garcia et al., 2003; Thomsen et al., 2001). The aim of this investigation was to study microbial processes related to methane seepage in shelf sediments. The main tasks were to reveal the distribution and identity of methanotrophic microorganisms, the zonation and magnitude of methane oxidation and to analyse the impact of methane venting on a sandy benthic habitat of the North Sea.

\section{Materials and methods}

\subsection{Water column and seafloor observations}

Visual observations of the Tommeliten sea floor were carried out with a Remotely Operated Vehicle (ROV "Sprint 103" of the Alfred Wegener Institute of Polar and Marine Research) during a cruise with R/V Heincke in June 2002 (HE-169) and with a towed video camera in October 2002 (HE-180). Gas flares in the water column were detected with a SES-2000 echosounder operated at different frequencies in the range of 10 to $100 \mathrm{kHz}$. The same parametric echosounder was used for high-resolution sub-bottom profiling at frequencies between 8 and $15 \mathrm{kHz}$. Video and echosounder images were used to select positions for sediment sampling.

\subsection{Sample collection and storage}

Sediment samples were collected with a vibrocorer $(4 \mathrm{~m}$ length; Institute of Baltic Sea Research) during the cruise HE-180 in October 2002. Three cores were recovered from seep areas (core 1860, 1866, 1904, Fig. 1) and one from a reference station (core 1867). Upon recovery, cores were sectioned in $1 \mathrm{~m}$ pieces and kept in their plastic bags during subsampling of porewater constituents (methane, sulphate, sulphide) and turnover rate measurements of methane and sulphate. Replicate subsamples were obtained from a $10 \mathrm{~cm}$ section every 10 (cores 1866 and 1904) or $20 \mathrm{~cm}$ (core 1860). Samples for lipid biomarkers, cell counts and DNA were collected from the same $10 \mathrm{~cm}$ sections of core 1904. Sediment samples for lipid analysis were transferred into pre-cleaned glass vials and stored at $-25^{\circ} \mathrm{C}$ until extraction. Sediments for microbiological analysis were fixed for fluorescent in situ hybridisation (FISH) or frozen for DNA extraction. Pieces of MDACs were collected from the SMTZ at station 1904 and stored at $-25^{\circ} \mathrm{C}$ until extraction. MDACs from the surface of the sea floor were collected earlier during a ROV expedition in 1998 (Hovland, 2002). Detailed protocols for the following methods can be obtained from http://www.metrol.org.

\subsection{Methane concentrations}

Methane concentrations from selected sediment horizons were determined according to the "head space" method from $5 \mathrm{ml}$ sediment fixed with $25 \mathrm{ml} \mathrm{NaOH}(2.5 \%$, w/v) in gas-tight glass vials as described previously (Treude et al., 2003). Immediately after sub-sampling, methane concentrations were determined on board using a gas chromatograph (Treude et al., 2003).

\subsection{Sulphate concentrations}

$5 \mathrm{ml}$ of wet sediment were fixed in $50 \mathrm{ml}$ corning vials with $25 \mathrm{ml}$ zinc acetate solution $(20 \%, \mathrm{w} / \mathrm{v})$. After vigorous shaking, sediment particles were separated by centrifugation and filtration. Sulphate concentrations were determined from an aliquot of the supernatant using a Waters HPLC system (Waters 512 HPLC pump, I.C.-Pak anion-column (Waters; WAT007355) $4.6 \times 50 \mathrm{~mm}$, Waters 730 conductivity detector). Isophtalic acid ( $1 \mathrm{mM})$ was used as a solvent at a constant flow rate of $1 \mathrm{ml} \mathrm{min}^{-1}$. Sulphate concentrations were corrected for porosity, which was determined according to Treude et al. (2003).

\subsection{Sulphide concentrations}

Total sulphide concentrations were determined using a combination of a WTW Multiline P4 multi meter equipped with a WTW pH/ION 340i ion meter with two coupled electrodes (WTW Ag 500/WTW Ag/S 5001) for sulphide concentration measurements and a WTW SenTix 41-3 electrode for $\mathrm{pH}$ measurements. The sulphide measuring section was calibrated against sulphide standards at pHs of 6, 7, 8 and 9 .

\subsection{Ex situ AOM and SR rate measurements}

Subsamples for turnover rate measurements were collected from core 1904 by plugging glass tubes $(1 \times 6 \mathrm{~cm})$ into a defined sediment horizon of ca $10 \mathrm{~cm}(\mathrm{n}=5$ for $\mathrm{AOM}$ and $\mathrm{SR}$, respectively) as described previously (Treude et al., 2005 and references therein). To prevent gas exchange, the tubes were sealed with butyl rubber stoppers and only briefly opened for radiotracer injection, i.e., $50 \mu 1{ }^{14} \mathrm{C}$-labelled methane and $5 \mu \mathrm{l}^{35} \mathrm{~S}$-labelled sulphate (tracer dissolved in water, $10 \mathrm{kBq}$ and $50 \mathrm{kBq}$, respectively). Sediment samples were incubated on board at in situ temperature $\left(4^{\circ} \mathrm{C}\right)$ for $24 \mathrm{~h}$ in the dark. 
After incubation, samples for AOM and SR rate (SRR) measurements were fixed like the methane and sulphate samples (see above). Further processing of AOM and SR rate samples was performed according to Treude et al. (2003) and references therein. Turnover rates were calculated according to the following formulas:

AOM rate $=\frac{{ }^{14} \mathrm{CO}_{2}}{{ }^{14} \mathrm{CH}_{4}+{ }^{14} \mathrm{CO}_{2}} \times \frac{\text { conc. } \mathrm{CH}_{4}}{\text { incubat. Time }}$

$\mathrm{SRR}=\frac{\mathrm{TRI}^{35} \mathrm{~S}}{{ }^{35} \mathrm{SO}_{4}^{2-}+\mathrm{TRI}^{35} \mathrm{~S}} \times \frac{\text { conc. } \mathrm{SO}_{4}^{2-}}{\text { incubat. Time }}$

Here, ${ }^{14} \mathrm{CO}_{2},{ }^{35} \mathrm{SO}_{4}^{2-}$ and $\mathrm{TRI}^{35} \mathrm{~S}$ are the activities (Bq) of carbon dioxide, sulphate and total reduced sulphur species, respectively, whereas conc. $\mathrm{CH}_{4}$ and conc. $\mathrm{SO}_{4}^{2-}$ are the concentrations of methane and sulphate at the beginning of the incubation.

\subsection{In vitro potential rates}

The subsampling techniques applied here have been proven successful for muddy sediments (Treude et al., 2003). To test the suitability for sandy sediments, we compared shortterm AOM and SR rate measurements with long-term in vitro measurements ( $1 \mathrm{wk}$ ) of sediments collected from three horizons (surface, at the sulphide peak, and deep horizons) according to a modified method of Nauhaus et al. (2002). For this study, $20 \mathrm{ml}$ sediment slurries were incubated with radiolabelled methane and sulphate $(\mathrm{n}=5$ for $\mathrm{AOM}$ and $\mathrm{SR}$ rates, respectively). The slurries consisted of $1 \mathrm{~cm}^{3}$ fresh sediment and methane saturated $(1.4 \mathrm{mM})$, artificial sea water media with $28 \mathrm{mM}$ sulphate (Widdel and Bak, 1992). As a control, slurries from one horizon $(100-150 \mathrm{~cm}$, core 1904) were incubated without methane. After incubation, sediment slurries were processed like those from short-term incubations.

2.8 Extraction of sediment and MDAC samples and preparation of derivatives

The extraction procedure and preparation of Fatty Acid Methyl Esters (FAMES) was carried out using proven methods (Elvert at al., 2003). Briefly, Total Lipid Extracts (TLE) were obtained from ca. $25 \mathrm{~g}$ of wet sediment collected from core 1904 and from two MDAC pieces (one collected from the surface of the sea floor and one from the SMTZ in core 1904). Prior to extraction, the MDAC pieces were disintegrated with HCL (2M). The TLE was extracted by subsequent ultrasonification using organic solvents of decreasing polarity. Internal standards of known concentration and carbon isotopic compositions were added prior to extraction. Esterified Fatty Acids (FAs) present in glyco- and phospholipids were cleaved by saponification with methanolic $\mathrm{KOH}$ solution. After extraction of the neutral lipid fraction from this mixture, FAs were methylated for analysis with $\mathrm{BF}_{3}$ in methanol yielding FAMES.
Neutral lipids were further separated into hydrocarbons, ketones and alcohols on a SPE silica glass cartridge ( $0.5 \mathrm{~g}$ packing). Prior to separation, the column was rinsed with $15 \mathrm{ml} n$-hexane/dichloromethane (95:5, $\mathrm{v} / \mathrm{v})$. After application of the neutral fraction, solvent mixtures of increasing polarity were subsequently added: (I) $5 \mathrm{ml} n$-hexane/dichloromethane (95:5, v/v), (II) $5 \mathrm{ml} n$-hexane/dichloromethane (2:1, v/v) and (III) $5 \mathrm{ml}$ dichloromethane/acetone $(9: 1, \mathrm{v} / \mathrm{v})$. Neutral lipid fractions (hydrocarbons (I), ketones (II) and alcohols (III), respectively) were collected and concentrated to $100 \mu \mathrm{l}$ using rotary evaporation. Finally, neutral lipid fractions were stored at $-20^{\circ} \mathrm{C}$ until further processing and/or analysis. Alcohols were analysed as trimethylsilyl (TMS) ethers. Shortly before analysis $(<1 \mathrm{wk})$, aliquots from selected alcohol fractions were dried under a stream of nitrogen. $100 \mu \mathrm{l}$ pyridine and $50 \mu \mathrm{l}$ bis(trimethylsilyl)triflouracetamid were added and the reaction was carried out for $1 \mathrm{~h}$ at $70^{\circ} \mathrm{C}$. After cooling, excess solvent was evaporated and the remaining TMS adducts were re-suspended in $50 \mu 1$ of $n$-hexane. TMS adducts were stored at $-20^{\circ} \mathrm{C}$ until Gas Chromatography (GC), Gas Chromatography-Mass Spectrometry (GC-MS) and Gas Chromatography-Isotope Ratio Mass Spectrometry (GC-IRMS) analysis.

Sediments and the two MDAC pieces were additionally analysed for the content of tetraether lipids. Tetraether lipids, which are contained in the alcohol fractions, were subjected to ether cleavage through HI treatment as reported previously yielding phytanes and biphytanes which can be analysed by GC, GC-MS and GC-IRMS analysis (Blumenberg et al., 2004; Kohnen et al., 1992). Briefly, $500 \mu \mathrm{l} \mathrm{HI} \mathrm{(57 \% )}$ and $500 \mu \mathrm{l}$ acetic acid (100\%) were added to a dried alcohol fraction and iodisation of ether bonds was promoted at $110^{\circ} \mathrm{C}$ for $4 \mathrm{~h}$. After cooling, alkyl iodides were extracted with $n$-hexane. Excess iodine was removed by adding sodium thiosulphate solution $(5 \%, w / v$ in water). Subsequently, the hexane phase was removed and dried. Alkyl iodides were reduced to alkanes in $0.5 \mathrm{ml}$ of tetrahydrofurane (THF) by adding lithium-aluminium hydride ( 2 spatula tips). Reduction of iodides was carried out at $110^{\circ} \mathrm{C}$ for $3 \mathrm{~h}$. After cooling, excess lithium-aluminium hydride was deactivated by the addition of deionised water. The supernatant solvent phase was removed, dried and stored at $-20^{\circ} \mathrm{C}$.

\subsection{Preparation of Dimethyl Disulphide (DMDS) adducts}

Double bond positions of monoenoic FAs were determined by analysis as DMDS adducts according to previously reported methods (Moss and Lambert-Fair, 1989; Nichols et al., 1986). Briefly, an aliquot of a selected sample (dissolved in $50 \mu \mathrm{l} n$-hexane) was treated with DMDS $(100 \mu \mathrm{l})$ and iodine-diethyl ether solution $(20 \mu \mathrm{l}, 6 \% \mathrm{w} / \mathrm{v})$. Formation of DMDS adducts was carried out at $50^{\circ} \mathrm{C}$ for $48 \mathrm{~h}$. After cooling, excess iodine was reduced with sodium thiosulphate $(5 \%$ 
$\mathrm{w} / \mathrm{v}$ in water). The organic phase was removed, dried and stored at $-20^{\circ} \mathrm{C}$.

2.10 Gas Chromatography, Gas Chromatography-Mass Spectrometry, Gas Chromatography-Isotope Ratio Mass Spectrometry

Concentrations, identities and stable carbon isotope ratios of individual compounds were determined by GC, GC-MS and GC-IRMS analyses, respectively. Instrument specifications and operation modes of the GC, GC-MS and GC-IRMS systems were set according to Elvert and co-workers (2003). Concentrations were calculated against internal standards. Identities of acquired mass spectra were compared to known standards and published data. The chemical structure of biphytanes are reviewed in Schouten et al. (1998): monocyclic biphytane reported here equals compound IV and bicyclic biphytane compound $\mathrm{V}$. Stable carbon isotope ratios are given in the $\delta$-notation against PDB. $\delta^{13} \mathrm{C}$-values of FAs and alcohols were corrected for the introduction of additional carbon atoms during derivatisation. Internal standards were used to monitor precision and reproducibility during measurements. Reported $\delta^{13} \mathrm{C}$-values have an analytical error of $1-2 \%$.

\subsection{Cell counts and fluorescence in situ hybridisation}

Selected sediment samples from core 1904 were fixed with $2 \%$ formaldehyde and stored at $4{ }^{\circ} \mathrm{C}$ until further analysis. Total cell numbers were quantified with the aid of epifluorescence microscopy after staining the cells with Acridine Orange according to Knittel et al. (2003). Sediments from above, below and within the AOM zone were analysed for the presence of archaea and bacteria by FISH with Horseradish Peroxidase (HRP)-labelled oligonucleotide probes and tyramide signal amplification (CARD-FISH) according to the method of Pernthaler et al. (2002). The CARD-FISH probes used in this study were EUB338, ARCH915 and ANME1350, purchased from biomers.net GmbH, Ulm, Germany. Oligonucleotide probes and instrument specification are presented in Knittel et al. (2005). Briefly, after $2 \mathrm{~h}$ fixation at $4^{\circ} \mathrm{C}$, formaldehyde fixed sediments were washed with $1 \times \mathrm{PBS}(10 \mathrm{mM}$ sodium phosphate, $130 \mathrm{mM} \mathrm{NaCl})$ and stored in $1 \times \mathrm{PBS} / \mathrm{EtOH}(1: 1, \mathrm{v} / \mathrm{v})$ at $-20^{\circ} \mathrm{C}$. These samples were diluted $1: 10$, treated by sonification and filtered on $0.2 \mu \mathrm{m}$ GTTP polycarbonate filters. Prior to filtration, filters were coated with agarose to prevent cell loss. In addition to ultrasonification, cells were permeabilised with lysozyme solution for $1 \mathrm{~h}$ at $37^{\circ} \mathrm{C}$ and subsequently hybridised with HRP labelled probe for $2 \mathrm{~h}$ at $35^{\circ} \mathrm{C}$. Finally, filters were incubated for $15 \mathrm{~min}$. in tyramide solution labelled with the fluorochrome Cy-3.

\subsection{DNA extraction and clone library construction}

Total community DNA was directly extracted from ca. $5 \mathrm{~g}$ of wet sediment (Zhou et al., 1996) from the AOM zone of core 1904. Crude DNA was purified with the Wizard DNA Clean-Up Kit (Promega, Madison, WI). Almost full-length archaeal and bacterial 16S rRNA genes from the extracted chromosomal DNAs were amplified using primers 20f (Massana et al., 1997) and Uni1392R (Lane et al., 1985) for archaea and GM3F (Muyzer et al., 1995) and GM4R (Kane et al., 1993) for bacteria. Polymerase chain reactions (PCRs) were performed with a Mastercycler Gradient (Eppendorf, Hamburg, Germany) as described previously (Ravenschlag et al., 1999), except that the annealing temperature was $58^{\circ} \mathrm{C}$ and $42^{\circ} \mathrm{C}$ for archaea and bacteria, respectively. PCR products of several reactions were combined and purified with the QiaQuick PCR Purification Kit (Qiagen, Hilden, Germany). DNA was ligated in the pGEM T-Easy vector (Promega, Madison, WI) and transformed into E. coli TOP10 cells (Invitrogen, Carlsbad, CA) according to the manufacturer's recommendations. Sequencing was performed by Taq cycle sequencing with a model ABI1377 sequencer (Applied Biosystems) with insert-specific and vector primers. The absence of chimeric sequences in the clone libraries was verified with the CHIMERA_CHECK program of the Ribosomal Database Project II. A total of 57 archaeal and 54 bacterial clones were partially sequenced $(\sim 0.5 \mathrm{~kb})$. Using the ARB software package, these sequences were calculated into existing phylogenetic trees by parsimony without allowing changes in the tree topology. Representative sequences of each cluster were then fully sequenced $(\sim 1.3 \mathrm{~kb})$ and matched against the NCBI data base (http://www.ncbi.nlm.nih.gov/BLAST). The sequence data reported here will appear in the EMBL, GenBank, and DDBJ nucleotide sequence databases under the accession numbers DQ007532 to DQ007540.

\section{Results}

The data presented in this study can be obtained from http: //www.wdc-mare.org/PangaVista?query=@Ref26689.

\subsection{Water column and seafloor observations}

Echosounder transects revealed several gas flares reaching from the sea floor to the sea surface (transducer depth) at $6^{\circ} 29.92^{\prime} \mathrm{N}, 2^{\circ} 59.80^{\prime} \mathrm{E}$ in an area of ca. $3500 \mathrm{~m}^{2}$ (Figs. 1, 2). A small area with 4 single plumes was also found at $6^{\circ} 29.56^{\prime} \mathrm{N}, 2^{\circ} 59.25^{\prime}$ E. No plumes were detected outside of the seep areas within a larger area of $12 \mathrm{~km}^{2}$. Echosounder guided sampling of the gas flares and subsequent gas extraction showed high concentrations of methane within the plumes $(500 \mathrm{nM})$, which were up to 2 orders of magnitude above the background concentration ( $5 \mathrm{nM}$, data not shown). Similar to earlier findings (Hovland, 2002; Hovland and Judd, 1988), sea bottom observations with the ROV and the towed camera showed the presence of bubble streams emanating from small point sources of a few $\mathrm{cm}$ in diameter (Fig. 3a). White bacterial mats, most likely formed by giant 


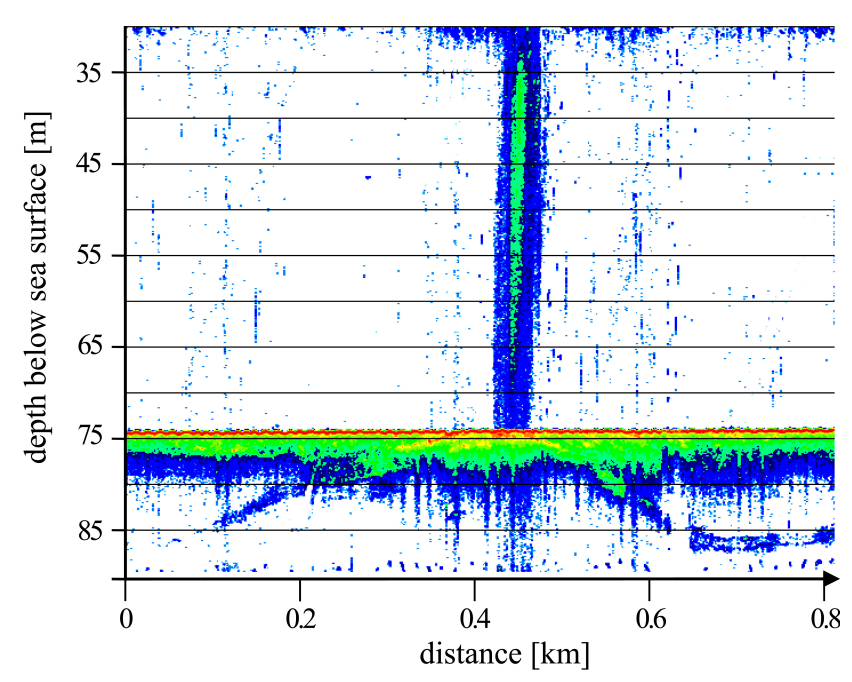

Fig. 2. Hydro acoustic image of a methane plume reaching from the sea floor to the sea surface. Ascending sub-surface horizons forming dome-like structures are visible. The image was recorded with a SES-2000 echosounder operated at 8 to $100 \mathrm{kHz}$.

sulphide oxidizing bacteria with a patch size of some decimetres were found in the same area (Figs. 1, 3b). No bubble emission was observed directly from bacterial mats. At various locations mostly situated north of the plume cluster, carbonate crusts with diameters ranging from decimetres to metres were exposed $10-50 \mathrm{~cm}$ above the sea floor (Figs. 1, 3c). These crusts were densely covered by several species of anthozoa and other sessile macrofauna typical of hard grounds (Fig. 3c). These animals were not found in the surrounding area characterized by sandy sediments. Furthermore, a comparably high density of demersal fish was observed in the vicinity of the crusts.

\subsection{Sediment layers and geochemical profiles}

The echosounder profiles showed several dome like structures in the seep area with a distinct sequence of layers narrowing towards the apex of each dome where the gas plumes were situated (Fig. 2). Station 1904 was furthest away from the plume, and station 1860 was closest. All cores obtained from the Tommeliten seep area (1904, 1866 and 1860, Fig. 1) contained four different horizons of sediments (Figs. 4a-6a): (1) the lowest $(350-240 \mathrm{~cm}$ b.s.f. in core 1904; 300-200 cm b.s.f. in core 1860) consisted of stiff marl followed by (2) a gassy layer of clay-silt (Fig. 3d) (240$175 \mathrm{~cm}$ b.s.f. in core $1904 ; 230-160 \mathrm{~cm}$ b.s.f. in core 1866 ; 200-125 cm b.s.f. in core 1860). (3) 10 to $40 \mathrm{~cm}$ of sand comprising MDACs (Fig. 3e) were overlying the clay-silt in cores 1904 and 1860. The presence of gas bubbles of ca $0.1-1 \mathrm{~cm}$ in diameter in the clay-silt (2), MDAC bearing sediments (3) and the first 10 to $20 \mathrm{~cm}$ just above the carbonate bearing sections gave the sediments a spongy appearance (Fig. 3d). (4) The upper most sediment layer consisted of carbonate-free sand $(165-0 \mathrm{~cm}$ b.s.f. in core $1904 ; 85-0 \mathrm{~cm}$ b.s.f. in core 1860). Hence, the narrowing of layers towards the apex of the dome visualized by echosounder images (Fig. 2) was reflected in the sedimentology (Figs. 4a, 6a). The sediment layering at station 1866 was different from station 1904 and 1860 as the (3) horizon containing MDACs was found at ca 75 to $85 \mathrm{~cm}$ b.s.f. within the (4) sandy sediments (Fig. 5a). No (1) marl section was recovered from core 1866, which was $230 \mathrm{~cm}$ long. Sediments at the reference station (recovered ca. $5 \mathrm{~km}$ away from the seep area) consisted of (4) a sandy surface horizon (0 to $100 \mathrm{~cm}$ b.s.f.) and an underlying (3) clay-silt horizon (100-400 cm b.s.f.). No gas bubbles or carbonates were observed at this station (data not shown).

The methane, sulphate and sulphide gradients in the cores from the Tommeliten seep area were influenced by their proximity to the gas plume and by the sediment layering. Because of the artefacts introduced by vibrocoring and subsequent sampling of the gassy and sandy sediments, fluxes of methane and sulphate cannot be calculated from the profiles. Nevertheless, the data indicate a distinct zonation of the processes of anaerobic methane consumption and associated sulphide production. At the reference station away from the seep, sediments contained methane concentrations $<0.1 \mu \mathrm{M}$ throughout the core. In contrast, within the seep area, methane concentrations reached supersaturation in the (2) clay horizon and the (3) MDAC-bearing sediments (core $1860=2.5,1866=1.4,1904=1.6 \mathrm{mM}$ ). Within the stiff marl sediments (1), the methane concentration was comparably low $(<0.2 \mathrm{mM})$ (Figs. 4a-6a). The AOM zone is defined here as the horizon with a distinct dip in methane and sulphate concentrations as well as a peak in sulphide concentrations. This was located between the (3) MDAC-bearing sediments and (4) the overlying sandy sediments in cores 1904 and 1860 , and in the lower sand section in core 1866 . In contrast to a typical sulphate-methane transition zone (SMTZ), sulphate was not depleted in the methane-rich zone. An advective influx of sulphate rich seawater into the sediment probably driven by gas ebullition has been observed at Hydrate Ridge (Tryon et al., 1999) and proposed for mud volcanoes at the Barbados Trench (Henry et al., 1996; Martin et al., 1996). However, these systems differ substantially from the Tommeliten seeps as they are characterised by vigorous gas venting and/or high heat flux. At Tommeliten, an advective influx of sulphate rich seawater down to some metres sediment depth appears very unlikely as only single bubbles emanating from the sea floor were observed. The distribution of methane and sulphate may be related to the sedimentology of the area. If methane is transported along vertical and horizontal gas bubble pathways, sulphate may be depleted locally, but not necessarily everywhere below a certain depth horizon. The methane profiles indicate that the gas front is limited to the sandy horizon above the clay-silt, coinciding with the sulphide peak and locally depleted sulphate concentrations. The marl below this layer contained rather low concentrations of methane, in contrast to typical SMTZ zones, 


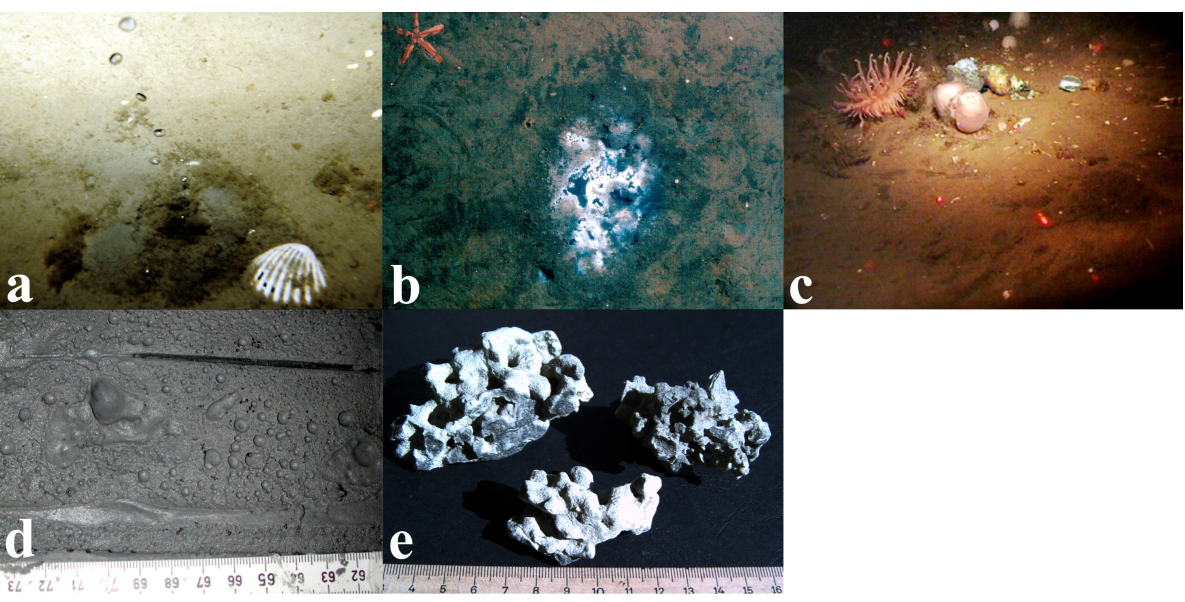

Fig. 3. Images of the seafloor observations showing (a) a stream of methane bubbles, (b) bacterial mats and (c) sessile macro fauna on exposed carbonates. (d) A lower section of core 1904 comprising methane-rich, clay-silt sediments and (e) MDACs recovered at the interface between methane-rich, clay-silt and overlying sandy sediments.

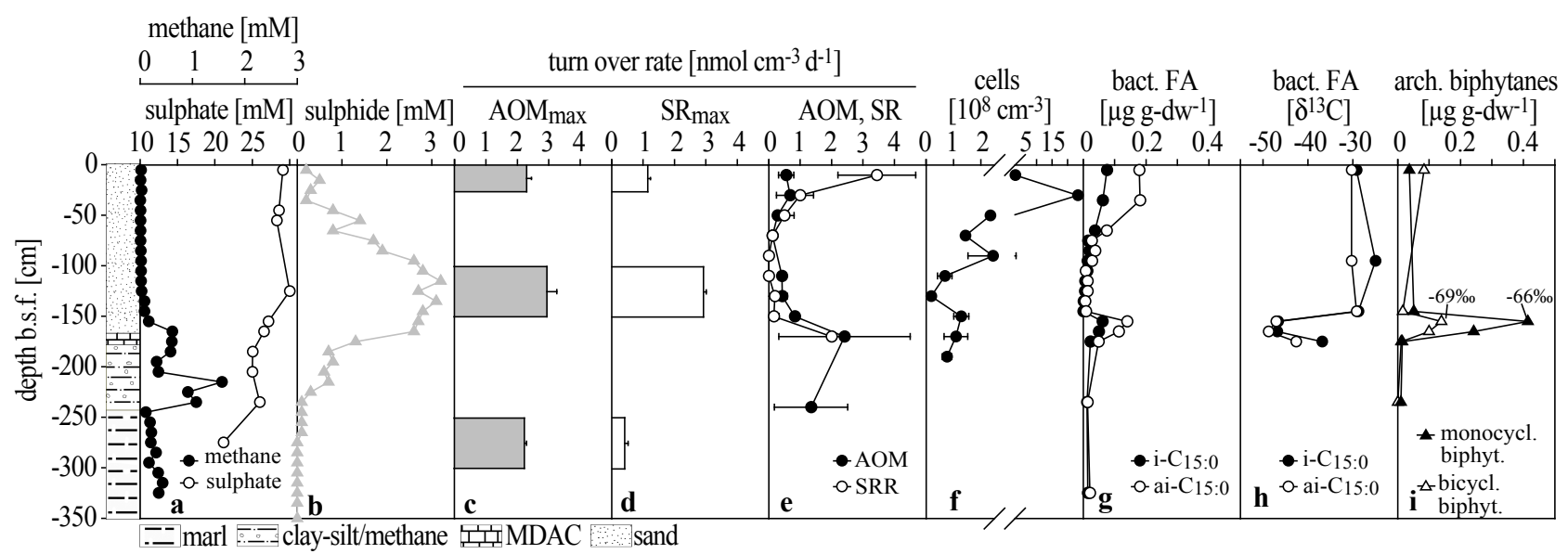

Fig. 4. Station 1904. (a) Methane and sulphate concentrations decline at depth of MDAC bearing sediments (150 cm b.s.f.). (b) Note that sulphide concentrations, (c) potential methane oxidation and (d) sulphate reduction rates, (e) ex situ measured methane oxidation and sulphate reduction rates, (f) cell counts, (g) concentrations and (h) stable carbon isotope values of selected, bacterial fatty acids and (i) concentrations of cleaved, archaeal tetraether lipids peak at the methane-sulphate transition zone. Errors are given as standard errors.

where methane concentration increase with depth below the sulphate penetration due to methanogenesis, or upward diffusing methane.

However, we cannot exclude that the sulphate concentrations below the AOM zone result from sampling artefacts. The sulphate profiles were probably disturbed by the subsampling of the sandy sediments. Porous sediments loose their porewater when a core is opened. Hence it is possible that bottom- and pore water from the top sediment section intruded deeper sediment layers after opening the core. Methane and sulphide concentrations were probably less disturbed, because subsamples for methane concentration measurements were taken first, and sulphide concentrations were measured with a macroelectrode, which was stuck into the middle of the core.
Above the AOM zone, methane concentrations declined to values $<0.04 \mathrm{mM}$. In core 1860 , methane concentrations remained comparably high above the carbonate-bearing horizon $(>0.25 \mathrm{mM})$ but declined to $<0.04 \mathrm{mM}$ in the top sediment horizon. At station 1904 and 1866, methane concentrations were below $0.01 \mathrm{mM}$ in the top $40 \mathrm{~cm}$ of the seabed (Figs. 4a, 5a). Sulphate concentrations declined slightly in the AOM zone from seawater values $(28 \mathrm{mM})$ to values between 23 (core 1904, 1866; Figs. 4a, 5a) and $15 \mathrm{mM}$ (core 1860; Fig. 6a). In each core, a distinct sulphide peak was measured just above the horizon in which methane declined with concentrations of $3.1 \mathrm{mM}$ (core 1904, $135 \mathrm{~cm}$ b.s.f.), $1.9 \mathrm{mM}$ (core $1866,115 \mathrm{~cm}$ b.s.f.) and $2.1 \mathrm{mM}$ (core 1860 , $55 \mathrm{~cm}$ b.s.f.), respectively (Figs. 4b-6b). Sulphide concentrations declined to values below detection limit in surface 


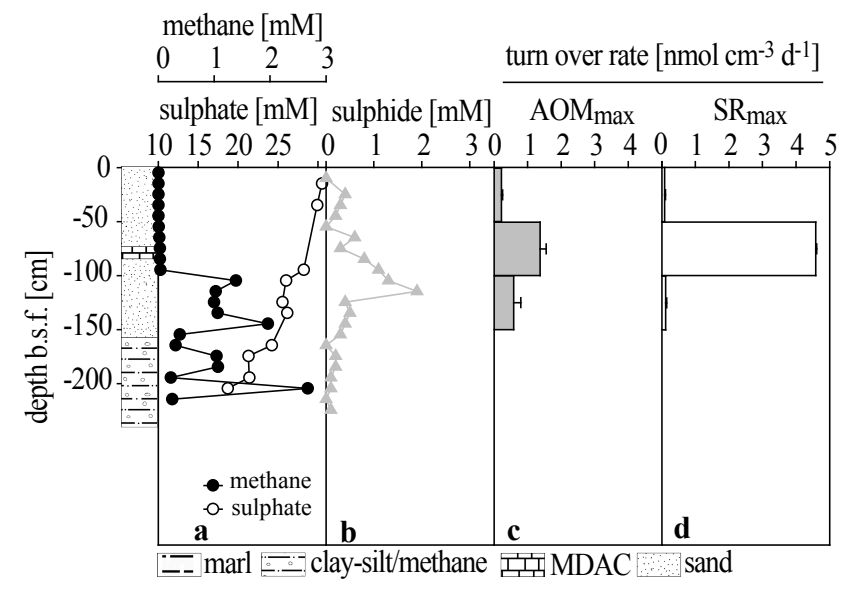

Fig. 5. Station 1866. (a) Methane and sulphate concentrations decline below carbonate bearing sediments $(100 \mathrm{~cm}$ b.s.f.). Homologous to core 1904, (b) sulphide concentrations and potential rates of (c) methane oxidation and (d) sulphate reduction are highest at the sulphate-methane transition zone. Errors are given as standard errors.

and bottom horizons. Sediments of the reference station did not show any detectable sulphide concentrations (data not shown).

\subsection{Ex situ AOM and SR}

In short-term ex situ incubations, AOM reached a maximum rate of $2.4 \mathrm{nmol} \mathrm{cm}^{-3} \mathrm{~d}^{-1}$ at $170 \mathrm{~cm}$ b.s.f. in core 1904 within the AOM zone. SR rates were also elevated in this horizon reaching $2 \mathrm{nmol} \mathrm{cm}^{-3} \mathrm{~d}^{-1}$. Unfortunately, no SR rates could be measured below this horizon due to sample loss. Rates in overlying horizons decreased to values ranging between 0.8 and $0.1 \mathrm{nmol} \mathrm{cm}^{-3}$ (Fig. 4e). Highest SR rates were detected in the surface horizon $\left(3.5 \mathrm{nmol} \mathrm{cm}^{-3} \mathrm{~d}^{-1}\right)$. AOM and SR rates were highly variable between replicate subsamples within one horizon leading to standard errors of up to $83 \%$ of the mean (Fig. 4e). If sulphate concentrations were artificially increased by subsampling artefacts in sands (see Sect. 3.2), this could lead to an overestimation of AOM and SR rates. However, most marine SRB have half saturation constants $(\mathrm{Km})$ of 70 to $200 \mu \mathrm{M}$ (Canfield et al., 2005 and reference therein), thus we do not expect a large effect on $\mathrm{AOM}$ and SR rates from this potential artefact.

\subsection{In vitro rates at methane saturation}

In vitro $\mathrm{AOM}$ and $\mathrm{SR}$ rates $\left(\mathrm{AOM}_{\max }, \mathrm{SR}_{\max }\right)$ measured in long-term incubations were in the same range as shipboard ex situ rate measurements. In vitro AOM and SR were highest in sediments collected from the AOM zone with 1.4 to 3 and 2.9 to $4.6 \mathrm{nmol} \mathrm{cm}^{-3} \mathrm{~d}^{-1}$, respectively (Figs. $4 \mathrm{c}, \mathrm{d}-$ $6 c, d)$. In these incubations, the ratio of AOM to SR was $1: 1$ in core $1904,0.3: 1$ in core 1866 and $0.5: 1$ core 1860 .

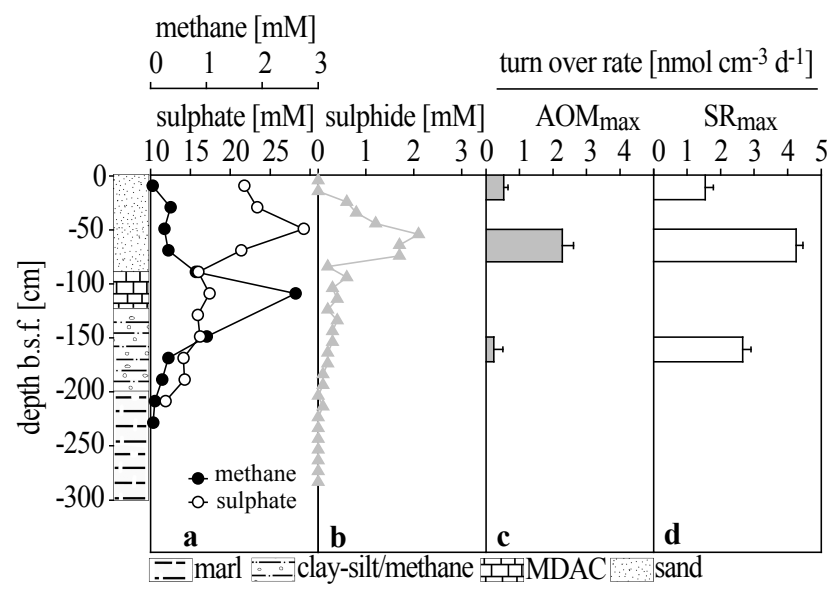

Fig. 6. Station 1860. (a) Methane and sulphate concentrations decline at depth of carbonate bearing sediments $(70 \mathrm{~cm}$ b.s.f.). Homologous to core 1904, (b) sulphide concentrations and potential rates of (c) methane oxidation and (d) sulphate reduction are highest in the AOM zone. Errors are given as standard errors.

The overall AOM and SR rates (in vitro as well ex situ) are very small and close to the detection limit of the applied methods $\left(\sim 0.1-0.5 \mathrm{nmol} \mathrm{cm}^{-3} \mathrm{~d}^{-1}\right)$. Hence, small differences in incubation conditions may lead to the observed deviation from a 1:1 ratio. The sampling horizons for the in vitro rate measurements were rather broad (i.e., $20-50 \mathrm{~cm}$ ), whereas the active AOM horizon was narrower. Hence, it appears very likely that the subsampling procedure as well as the subsequent slurry preparation mobilising substrates for SR introduces this variability. In sediment slurries from the AOM zone at station 1904, SR without methane was $70 \%$ lower compared to incubations with methane. This indicates a close coupling between $\mathrm{AOM}$ and $\mathrm{SR}$. $\mathrm{AOM}_{\max }$ and $\mathrm{SR}_{\max }$ were substantially lower in slurries obtained from horizons above and below the AOM zone (Figs. 4c, d-6c, d).

\subsection{Biomarker signatures}

\subsubsection{Sediments}

Concentration measurements of single lipid compounds showed maxima of specific bacterial FAs and archaeal isoprenoidal lipids in sediments from the AOM zone of core 1904 (150-180 cm b.s.f.; Figs. 4g, i, Table 1). At this horizon, stable carbon isotope analysis revealed the highest depletion in ${ }^{13} \mathrm{C}$ with minimum values of $-79 \%$ ( $s n 2$ hydroxyarchaeol) in archaeal diether lipids (Fig. 7) and $-50 \%$ o (ai- $\left.\mathrm{C}_{15: 0}\right)$ in bacterial FAs (Figs. 4h, 9). The concentration of both archaeal and bacterial lipids decreased just above and below the AOM zone where these biomarkers were also less depleted. Archaeal lipids found in the AOM zone were dominated by the glycerol diether archaeol and the decomposition products of both diether and tetraether 


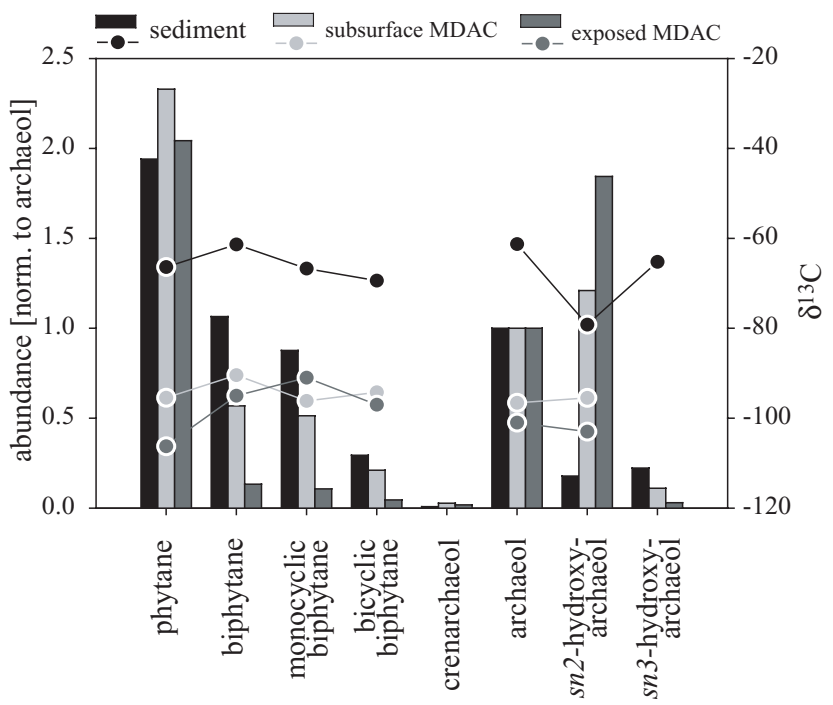

Fig. 7. Abundance (bars) and stable carbon isotope composition (circles) of cleaved, archaeal tetraether and whole diether lipids extracted from sediments and MDACs at the sulphate-methane transition zone ( $155 \mathrm{~cm}$ b.s.f.) of core 1904 and from surface MDACs recovered by a ROV. Abundances were normalised to archaeol. Note the constant offset in $\delta^{13} \mathrm{C}$-values between sediments and MDACs.

Table 1. Lipid biomarker concentrations extracted from sediments at the sulphate-methane transition zone ( $155 \mathrm{~cm}$ b.s.f.) of core 1904.

\begin{tabular}{|c|c|}
\hline \multicolumn{2}{|c|}{ Bacterial fatty acids } \\
\hline Component & $\begin{array}{c}\text { Concentration } \\
{[\text { ng g-dw-1] }}\end{array}$ \\
\hline $\mathrm{C} 14: 0$ & 145 \\
\hline $\mathrm{i}-\mathrm{C} 15: 0$ & 61 \\
\hline ai-C15:0 & 140 \\
\hline $\mathrm{C} 15: 0$ & 72 \\
\hline $\mathrm{i}-\mathrm{C} 16: 0$ & 25 \\
\hline $\mathrm{C} 16: 1 \omega 9 \mathrm{c}$ & 88 \\
\hline $\mathrm{C} 16: 1 \omega 7 \mathrm{c}$ & 21 \\
\hline $\mathrm{C} 16: 1 \omega 5 \mathrm{c}$ & 11 \\
\hline C16:0 & 604 \\
\hline $\mathrm{i}-\mathrm{C} 17: 0$ & 15 \\
\hline ai-C17:0 & 43 \\
\hline C17:0 & 39 \\
\hline C18:2 & 215 \\
\hline $\mathrm{C} 18: 1 \omega 9 \mathrm{c}$ & 270 \\
\hline $\mathrm{C} 18: 1 \omega 7 \mathrm{c}$ & 58 \\
\hline C18:0 & 345 \\
\hline
\end{tabular}

\section{Archaeal ether lipids}

\begin{tabular}{|c|c|}
\hline Component & $\begin{array}{c}\text { Concentration } \\
{\left[\text { ng g-dw }{ }^{-1}\right]}\end{array}$ \\
\hline crocetane & 21 \\
\hline PMI:0 & 56 \\
\hline PMI: 1 & 36 \\
\hline$\Sigma$ PMI:2 & 158 \\
\hline इPMI:3 & - \\
\hline इPMI:4 & 15 \\
\hline archaeol & 473 \\
\hline sn2-hydroxyarchaeol & 84 \\
\hline sn3-hydroxyarchaeol & 105 \\
\hline phytane & 918 \\
\hline biphytane & 504 \\
\hline monocycl. biphytane & 414 \\
\hline bicycl. biphytane & 139 \\
\hline crenarchaeol & 4 \\
\hline
\end{tabular}

lipids, i.e. phytane and biphytanes with $\delta^{13} \mathrm{C}$-values ranging from $-60 \%$ o to $-70 \%$ (Table 1, Fig. 7). sn2- and sn3-hydroxyarchaeol ( $\Sigma$ hydroxyarchaeol) were less abundant relative to archaeol with a ratio of 0.4:1. Concentrations of the biphytanes decreased with increasing degree of cyclisation (Fig. 7). Compared to the di- and tetraethers, archaeal isoprenoidal hydrocarbons were approximately one order of

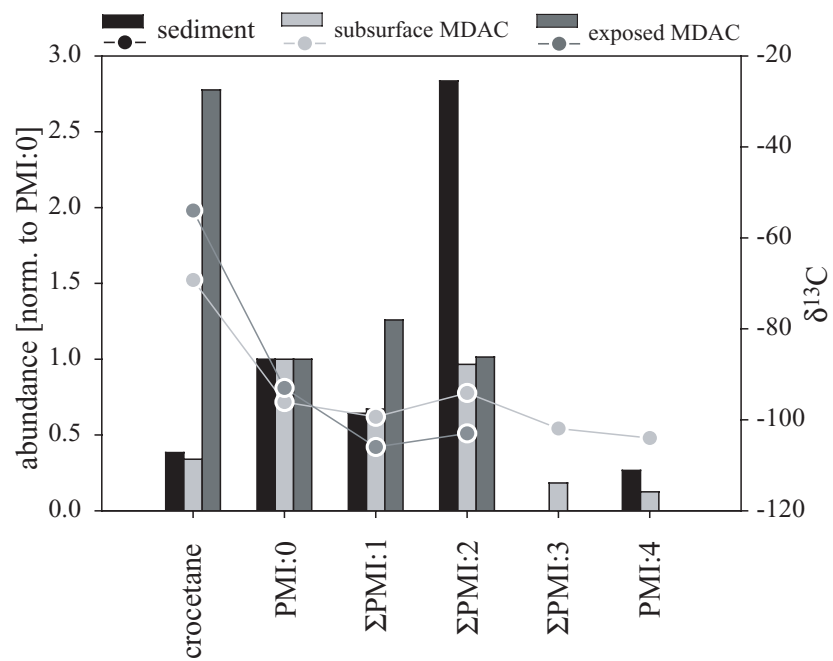

Fig. 8. Abundance (bars) and stable carbon isotope composition (circles) of archaeal, isoprenoid hydrocarbon lipids extracted from sediments and MDACs of the AOM zone $(155 \mathrm{~cm}$ b.s.f.) of core 1904 and from surface MDACs recovered by a ROV. Abundances were normalised to PMI:0. Note that concentrations of crocetane are ca. 7.5-fold increased in surface MDACs. Low concentrations prohibited $\delta{ }^{13} \mathrm{C}$-measurements of hydrocarbons in the sediment.

magnitude lower in concentration (Table 1). As a result, the stable carbon isotope composition of these compounds could not be measured (required minimum concentration:

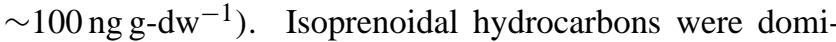
nated by 2,6,10,15,19-pentamethylicosenes with two double bonds ( $\Sigma$ PMI:2; 3 isomers) followed by PMI:0 and PMI:1 (Fig. 8).

The FA fraction in sediments of the AOM zone was dominated by $\mathrm{C}_{16: 0}$, followed by $\mathrm{C}_{18: 1 \omega 9}, \mathrm{C}_{18: 0}, \mathrm{C}_{14: 0}$ and $\mathrm{C}_{18: 2}$. FAs that are putatively specific for SRB involved in $\mathrm{AOM}$ such as $\mathrm{C}_{16: 1 \omega 5}$, $\mathrm{i}-\mathrm{C}_{15: 0}$ and ai- $\mathrm{C}_{15: 0}$ (Blumenberg et al., 2004; Elvert et al., 2003), were approximately 5 to 50 times lower in concentration compared to $\mathrm{C}_{16: 0}$ in Tommeliten sediments (Table 1). However, in contrast to abundant FAs, stable carbon isotope compositions of $\mathrm{i}-\mathrm{C}_{15: 0}$ and ai- $\mathrm{C}_{15: 0}$ showed a depletion in ${ }^{13} \mathrm{C}(-46.5$ and $-47 \%$, respectively; Figs. 4h, 9). The high abundances of $\mathrm{C}_{16: 1 \omega 9}$ and $\mathrm{C}_{18: 2}$ are uncommon, however, the $\delta^{13} \mathrm{C}$-values $(-33 \%$ and ca. $-30 \%$, respectively) give evidence that the source organisms are not involved- or heterotrophically feeding on AOM derived biomass. $\mathrm{C}_{18: 2}$ FAs are commonly found in eukaryotes. However, high concentrations of $\mathrm{C}_{18: 2}$ and low concentrations of cholesterol in the AOM zone, in contrast to a reversed pattern of these lipids in the top sediment section (data not shown), indicate that the $\mathrm{C}_{18: 2} \mathrm{FA}$ is not of eukaryotic origin. Multiple sources of allochthonous and autochthonous bio- and necromass are to be expected for the Tommeliten area. Hence, a further assignment of these lipids to potential source organisms remains speculative. 


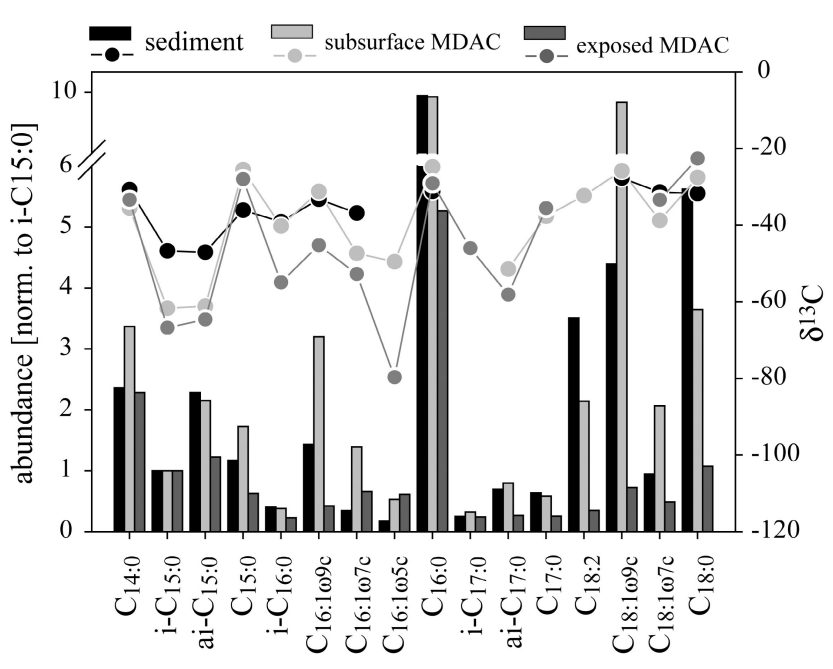

Fig. 9. Abundance (bars) and stable carbon isotope composition (circles) of fatty acids extracted from sediments and MDACs of the AOM zone $(155 \mathrm{~cm}$ b.s.f.) of core 1904 and from surface MDACs recovered by a ROV. Abundances were normalised to i$\mathrm{C}_{15: 0}$. i- $\mathrm{C}_{15: 0}$, ai- $\mathrm{C}_{15: 0}$ and $\mathrm{C}_{16: 1 \omega 5}$, are among the most depleted fatty acids. Note the offset in $\delta^{13} \mathrm{C}$-values between sediments and MDACs.

\subsubsection{Methane derived authigenic carbonates}

Lipid analysis revealed that MDACs from the Tommeliten seep contained specific archaeal and bacterial lipids. $\delta^{13} \mathrm{C}$ values of these compounds were 20-30\%o-lower in comparison to those extracted from sediment of the AOM zone of station 1904 (Figs. 7-9). In contrast to the AOM zone, the di- and tetraether fraction in the subsurface MDACs was dominated by $s n 2$-hydroxyarchaeol, which was slightly more abundant than archaeol (archaeol: $\Sigma$ hydroxyarchaeol=1:1.6). The surface MDACs even reached a ratio of archaeol to Ehydroxyarchaeol of 1:1.9 (Fig. 7). The suite of biphytanes found in sediments of the AOM zone was also present in the subsurface and surface MDACs. Furthermore, the biphytanes in the MDACs and in sediments of the AOM zone showed a similar abundance pattern. I.e., concentrations of the biphytanes decreased with higher degrees of cyclisation. However, in contrast to sediments of the AOM zone, the abundance of biphytanes relative to archaeol and phytane was lower in the subsurface MDACs and lowest in surface MDACs (Fig. 7). Furthermore, PMIs in the MDACs showed higher degrees of saturation (Fig. 8) and a higher number of isomers compared to sediments of the AOM zone. $\Sigma$ PMI:1

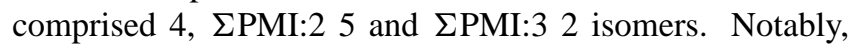
surface MDACs contained very high amounts of crocetane. Stable carbon isotope compositions of diethers, tetraethers and isoprenoid hydrocarbons were uniformly $<-90 \%$, both in the subsurface and the surface MDACs. An exception was crocetane showing $\delta^{13} \mathrm{C}$-values of -70 and $-55 \%$ in the subsurface and the surface MDACs, respectively (Fig. 8). Vari- ations in $\delta^{13} \mathrm{C}$-values among the PMI isomers were small with a maximum of $\pm 2 \%$. As with the biphytanes, the FA abundance pattern of the subsurface MDACs showed comparably high similarities to the pattern found in sediments of the AOM zone, whereas the abundance pattern of the surface MDACs showed lower similarities (Fig. 9). Subsurface MDACs contained roughly twice as much i- $\mathrm{C}_{15: 0}$ than ai$\mathrm{C}_{15: 0}$ while this ratio was almost $1: 1$ in surface carbonates. In the subsurface MDACs, $\mathrm{i}-\mathrm{C}_{15: 0}$ and ai- $\mathrm{C}_{15: 0}$ were the most ${ }^{13} \mathrm{C}$-depleted FAs with values down to $-62 \%$. In contrast, the most ${ }^{13} \mathrm{C}$-depleted FA found in the surface MDACs was $\mathrm{C}_{16: 1 \omega 5}$ with a $\delta^{13} \mathrm{C}$-value of $-80 \%$ while $\mathrm{i}-\mathrm{C}_{15: 0}$ and ai- $\mathrm{C}_{15: 0}$ showed values of $-67 \%$ and $-65 \%$, respectively (Fig. 9).

\subsection{Archaeal and bacterial clone libraries}

One archaeal and one bacterial clone library were constructed from a sediment sample from the AOM zone of station 1904 to study the microbial diversity in the AOM zone. A total of 57 archaeal and 54 bacterial clones were partially sequenced $(\sim 0.5 \mathrm{~kb})$. From each phylogenetic group, one representative sequence was almost fully $(\sim 1.5 \mathrm{~kb})$ sequenced. The obtained $16 \mathrm{~S}$ rDNA archaeal clone library showed a low diversity in comparison to previous publications of methane seep systems (Mills et al., 2003; Orphan et al., 2002; Teske et al., 2002). Two different phylogentic groups of archaea were detected (Table 2). The ANME-1b cluster (Methanosarcinales) accounted for $98 \%$ of obtained sequences. The second group comprised a single clone sequence, which belongs to the Marine Benthic Group D (Thermoplamatales). Other ANME groups or methanogens were not detected.

The bacterial clone library consisted of seven uncultivated, methane seep-related lineages. The next relatives to all sequences obtained are commonly found in marine cold seep sediments (Table 2). Most abundant were clones of the $\delta$ Proteobacteria comprising sequences of the putative bacterial partner for AOM (26\% of bacterial clone sequences), i.e. the Seep-SRB1 cluster (Knittel et al., 2003). One other abundant group among the $\delta$-Proteobacteria were the Desulfoarculaceae $(26 \%)$. $38 \%$ of bacterial sequences were distantly related to the Haloanaerobiales, which belong to the Firmicutes.

\subsection{Total cell counts and ANME-1 abundance}

Direct cell counts showed highest numbers in surface sediment horizons $\left(23.2 \times 10^{8}\right.$ cells $\mathrm{cm}^{-3}$ at $30 \mathrm{~cm}$ b.s.f. $)$. Cell counts decreased below this horizon to values $<0.2 \times 10^{8}$ cells $\mathrm{cm}^{-3}$ at $130 \mathrm{~cm}$ b.s.f. but showed an increase in sediments of the AOM zone $\left(1.1-1.3 \times 10^{8}\right.$ cells $\mathrm{cm}^{-3}$ at $150-$ $170 \mathrm{~cm}$ b.s.f.). In this horizon, probing with CARD-FISH targeting ANME-1 cells resulted in positive signals (Fig. 10). Only single cells or chains of up to three cells were observed. Bacterial partners physically attached to ANME-1 were not 
Table 2. Archaeal and bacterial $16 \mathrm{~S}$ rDNA clone libraries obtained from sediments at the methane transition zone (155 cm b.s.f.) of core 1904.

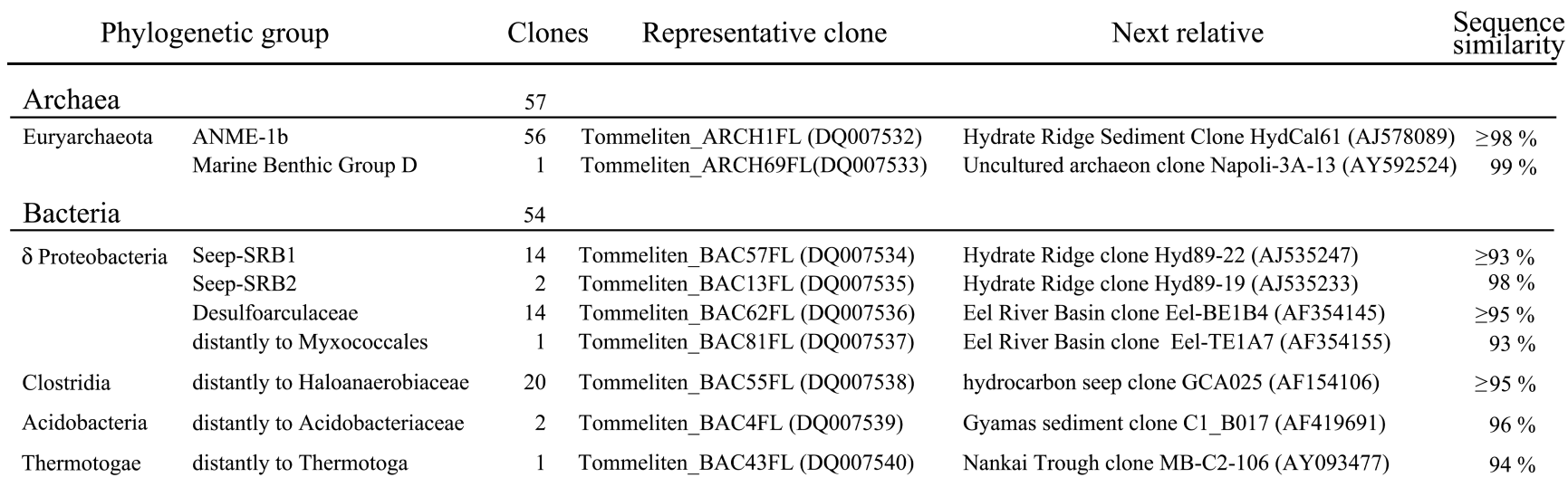

observed. Specific CARD-FISH counts resulted in $1.45 \times 10^{7}$ ANME-1 cells $\mathrm{cm}^{-3}$ sediment. The overlying horizon $(110 \mathrm{~cm}$ b.s.f.) contained very low numbers of ANME- 1 cells $\left(<3 \times 10^{5}\right.$ cells $\left.\mathrm{cm}^{-3}\right)$, whereas ANME-1 could not be detected in an underlying horizon $(190 \mathrm{~cm}$ b.s.f.).

\section{Discussion}

\subsection{Methane emission from the Tommeliten seep area}

Two decades after the discovery of gas seeps in the Tommeliten area by Hovland and Judd (1988), we revisited this area for video and biogeochemical surveys. The Tommeliten area is located in the central North Sea $\left(56^{\circ} 29.90^{\prime} \mathrm{N}\right.$, $2^{\circ} 59.80^{\prime} \mathrm{E}$ ) above three salt diapiers. Here, the so-called Delta structure has pierced the enclosing sedimentary rocks allowing methane to migrate to surface sediments. During ROV surveys, Hovland and Judd (1988) identified several small gas vents emitting single streams of methane bubbles from the sandy seabed into the hydrosphere. High reflective, small patches ( $<5 \mathrm{~m}$ across, $\sim 0.5 \mathrm{~m}$ deep) noted on short-range side-scan sonar records, which the authors termed "eyed pockmarks", were found to comprise MDAC crusts serving as a hard substrate for a variety of anthozoa such as sea-anemones and sea pens. Furthermore, it was estimated that the flux of gas from the wider seep area of $6500 \mathrm{~m}^{2}$ was $47 \mathrm{~g} \mathrm{CH}_{4} \mathrm{~m}^{-2} \mathrm{yr}^{-1}$ (Hovland and Judd, 1992; Hovland et al., 1993). Two decades later, our observations provide evidence that the Tommeliten seep area is still active. Here, several gas flares reaching almost to the sea surface were recorded by hydroacoustic profiling (Fig. 2) and video surveys provided evidence for bubble streams being emitted from the sandy sea floor (Fig. 3a). Hence, deep mixing of North Sea waters likely enhances the contribution to atmospheric methane from the Tommeliten seep area. Video observations also showed microbial mats of filamentous, presumably thiotrophic bacteria (Fig. 3b) and reef like structures of MDACs as already described by Hovland and Judd (1988).

Such features as observed at Tommeliten are typical for active cold seeps on continental margins and generally indicate high methane fluxes and turnover rates (Boetius and Suess, 2004; Joye et al., 2004; Michaelis et al., 2002; Orphan et al., 2004; Treude et al., 2003). However, we found only few highly focused point sources in the sandy seabed and very patchy, small microbial mats pointing to very restricted AOM zones close to the sea floor.

\subsection{Control of methane efflux from seep sediments}

Our study provides evidence that methane flux at the Tommeliten seeps is controlled by a combination of geological and microbial processes as illustrated in Fig. 11. The shallow seismic profiles show strong, ascending reflectors in the sediment (Fig. 2). Moreover, ascending and discontinuous reflectors on seismic plots of deep sediment layers (Hovland, 2002; Hovland and Judd, 1988) indicate that the process of local gas venting may have occurred several times in the history of Tommeliten. At present, the position of the methane plumes together with direct observations of methane bubbles (Figs. 1, 3a) give evidence for seepage pathways at the crest of the marl domes that allow for emission of free gas, circumventing microbial consumption (Fig. 11-II). Our observations from vibrocorer sampling indicate that the marl sediments represent a barrier to gas flow. A shallower depth and narrowing of the marl boundary in the vicinity of plumes as observed previously (Hovland and Judd, 1988) and in this study (Figs. 4a, 6a) suggests that subsurface gas pressure lifts sediments (Fig. 11-I). As a consequence, the marl may locally crack, allowing an advection of methane into and within the overlying clay-silt sediments. At the station 1860 closest to the gas plume, the marl horizon was missing. It is possible 


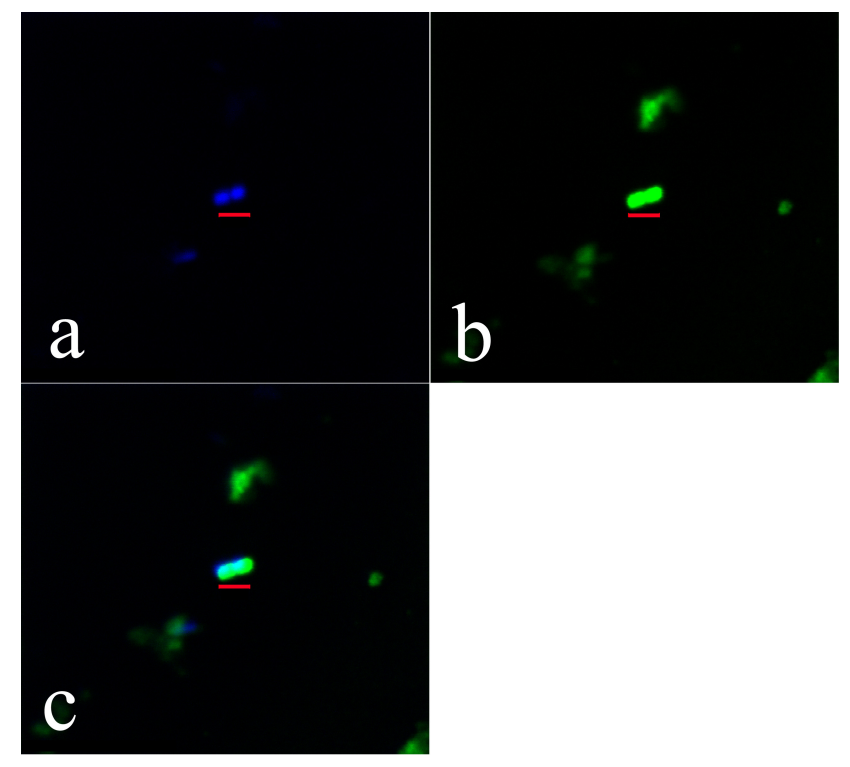

Fig. 10. Individual cells of ANME-1 archaea from sediments of the AOM zone $(155 \mathrm{~cm})$ of core 1904 (a) visualised with $4^{\prime}, 6^{\prime}$ diamidino-2-phenylindole (DAPI), (b) cy-3 horseradish peroxidaselabeled oligonucleotide probe ANME1-350 and tyramide signal amplification (CARD-FISH) and (c) an overlay of both images. The red scale bar represents $2 \mu \mathrm{m}$.

that the position of the gas vents is connected to the distribution of sands, which facilitate the passage of free gas bubbles compared to clays.

Within the sediments, methane is most likely advecting horizontally in the clay-silt layer above the marl. Here, it is partially consumed in a very distinct subsurface horizon of no more than $20 \mathrm{~cm}$ between the MDACs (horizon 3) and the sandy sediments (horizon 4) (Fig. 11-III). The decline of methane concentrations in this AOM zone coincided with increased concentrations of ${ }^{13} \mathrm{C}$-depleted lipid biomarkers, cell abundances as well as with relatively elevated rates of AOM and SR measured by in vitro and ex situ incubations.

The ex situ and in vitro AOM and SR rates at the Tommeliten seep AOM zone are 2 to 3 orders of magnitude lower in comparison to highly active cold seeps such as Hydrate Ridge and the Gulf of Mexico (Boetius et al., 2000; Joye et al., 2004; Treude et al., 2003). Nevertheless, AOM apparently consumes all the methane diffusing into the sands. With respect to the abundance of ANME- 1 cells $\left(1.5 \times 10^{7}\right.$ cells $\mathrm{cm}^{-3}$ ) and the average AOM rate in sediments of the AOM zone $\left(2.4 \mathrm{nmol} \mathrm{cm}^{-3} \mathrm{~d}^{-1}\right)$, the cell-specific AOM rate at Tommeliten was $\sim 0.17 \mathrm{fmold}^{-1}$. This value is comparable to highly active seeps. At Hydrate Ridge, ex situ measurements of AOM showed near surface peaks with average values of 1.1 and $1.3 \mu \mathrm{mol} \mathrm{cm}{ }^{-3} \mathrm{~d}^{-1}$, respectively (Treude et al., 2003; study site Beggiatoa field 2 at 2.5 and $6.5 \mathrm{~cm}$ b.s.f.). In these horizons, ca. $0.9 \times 10^{8}$ and $0.6 \times 10^{8}$ ANME-2/Seep-SRB1 aggregates per $\mathrm{cm}^{3}$ were detected, re-

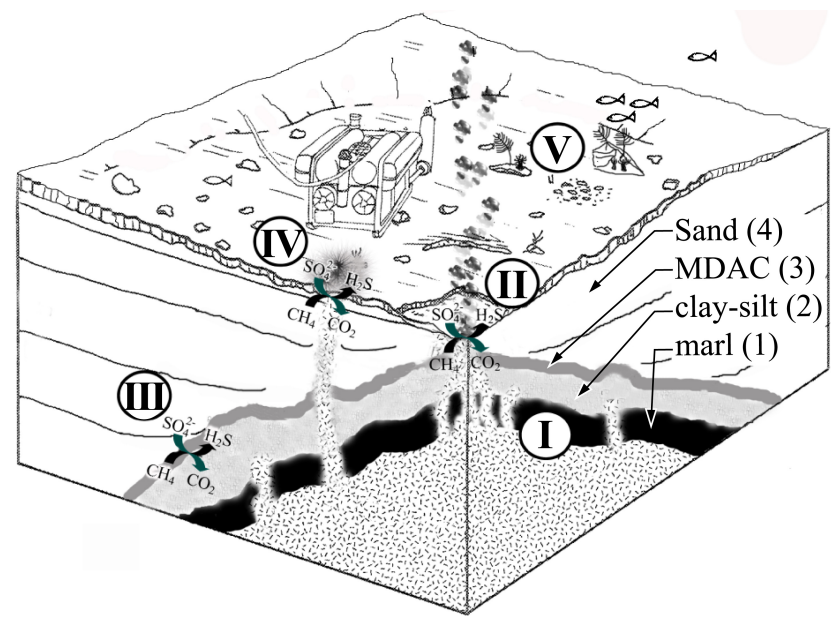

Fig. 11. Schematic overview of seepage and related processes at Tommeliten modified from Hovland and Judd (1988). The different sediment horizons are indicated. (I) methane migrates through cracks in the uplifted marl into overlying, clay-silt sediments. (II) sedimentary pathways at the crest of the marl dome permit the escape of free gas, circumventing microbial consumption. (III) subsurface, AOM depletes uprising methane at the interface between clay silt and sandy sediments where MDACs precipitate. With time and/or reduced methane fluxes, seepage at Tommeliten is sealed of as indicated by (IV) patches of thiotrophic, bacterial mats on the seafloor. These are commonly associated to high AOM rates in shallow surface sediments consuming uprising methane. (V) MDACs are precipitated in near-surface sediments. These provide a hard substrate for sessile macro fauna after exposure.

spectively (Treude et al., 2003). An average aggregate at Hydrate Ridge was found to consist of ca. 100 archaeal and 200 SRB cells (Boetius et al., 2000). Hence, cell-specific $\mathrm{AOM}$ rates are ranging between 0.13 and $0.21 \mathrm{fmol} \mathrm{d}^{-1}$. These values are in good agreement with in vitro measurements from Hydrate Ridge. Nauhaus et al. (2005) measured in vitro AOM rates of $2.5 \mu \mathrm{mol} \mathrm{g-dw}-1 \mathrm{~d}^{-1}$ in sediments from a Beggiatoa site, which contained $0.9 \times 10^{8}$ aggregates $\mathrm{g}-\mathrm{dw}^{-1}$. This corresponds to a cell specific rate of $0.28 \mathrm{fmol} \mathrm{d}^{-1}$. Other AOM systems such as the ANME-1 dominated microbial mats from the Black Sea were found to contain ca. $4 \times 10^{10}$ ANME- 1 cells $\mathrm{cm}^{-3}$ (Knittel et al., $2005)$. Corrected for porosity ( $\sim 87 \%$, Treude personal communication), in vitro AOM at the Black Sea microbial mats was ca. $5.3 \mu \mathrm{mol} \mathrm{cm}{ }^{-3} \mathrm{~d}^{-1}$ (Nauhaus et al., 2005) which corresponds to a cell-specific rate of $0.13 \mathrm{fmol} \mathrm{d}^{-1}$. In conclusion, the capacity for AOM at methane seep systems appears to be mainly related to the biomass and distribution of the AOM community, which is in turn regulated by the availability of methane and sulphate.

The sea floor observations of patches of presumably thiotrophic mats, above blackish, reduced sediments (Figs. 6b, 11-IV), give evidence for another type of patchy hot spot of microbial activity just beneath the sea floor, 
possibly AOM as indicated by previous observations of free methane trapped below microbial mats (Hovland, 2002). However, we were not able to sample these sediments with our tools during the R/V Heincke expeditions. The imprint of ${ }^{13} \mathrm{C}$-depleted archaeal and bacterial lipids in MDACs exposed at the sea floor also provide evidence of AOM activity and carbonate precipitation in near surface sediments at Tommeliten. This may have occurred just below the oxic interface in the sediment at times of higher gas flux. It is possible that the precipitation of carbonates in the AOM zone leads to a self-sealing of gas leakage pathways (Hovland, 2002). Subsequently to precipitation, the surface MDAC crusts may have been exposed due to sediment erosion. However, at present, no seepage was observed at the crusts (Hovland, 2002; Hovland and Judd 1988; this work). Today the exposed MDAC crusts are providing a niche for sessile hard substrate fauna, which is unusual for the sandy seabed of the central North Sea (Figs. 3c, 11-V). Furthermore, the crusts also attract demersal fish. Hence, these observations indicate that seepage related carbonates, which outcrop the seafloor, attract mega fauna organisms.

\subsection{Distribution and identity of methanotrophic communi-} ties

Specific lipid biomarkers with typically low $\delta^{13} \mathrm{C}$-values in sediments and MDACs of the Tommeliten seep area provide evidence for anaerobic methanotrophic communities associated with gas seepage. The differences in the biomarker patterns in sediments of the AOM zone and in the surface and subsurface MDACs indicate the presence of different groups of methanotrophs. Sediments of the AOM zone host a methanotrophic community dominated by ANME-1. MDAC pieces from that zone show a lipid pattern indicative of a mixed ANME-1/ANME-2 community whereas the exposed MDAC crusts contain a biomarker signature typical of ANME-2 communities, as discussed in the following:

\subsubsection{ANME-1 community in sediments of the AOM zone}

${ }^{13} \mathrm{C}$-depleted acyclic and cyclic biphytanes were found in relatively high abundances in sediments of the AOM zone (Fig. 7). Biphytanes are present in various methanogenic archaea and planktonic crenarchaeota (De Rosa and Gambacorta, 1988; Koga et al., 1993; Schouten et al., 2002). However, a substantial $\delta^{13} \mathrm{C}$-depletion as observed here and in other seep environments points to methanotrophic organisms. A similar lipid pattern as in the Tommeliten AOM zone was found in microbial mats from the Black Sea. These mats were dominated by ANME-1, as shown by microscopic observation based on FISH (Blumenberg et al., 2004; Knittel et al., 2005; Michaelis et al., 2002). Blumenberg et al. (2004) also showed that biphytanes are absent or rare in ANME-2 dominated microbial mats and proposed to use biphytanes as specific indicators for ANME-1 communities. Further- more, in sediments of the AOM zone, the low ratio of sn2hydroxyarchaeol relative to archaeol (0.2:1, Fig. 7), both of which are ${ }^{13} \mathrm{C}$-depleted, matches typical ANME-1 signatures known from other cold seep sediments and MDACs (Aloisi et al., 2002; Blumenberg et al., 2004; Hinrichs et al., 1999, 2000; Teske et al., 2002). In contrast, a ratio of 2:1 or higher was found in ANME-2 dominated systems (Blumenberg et al., 2004; Elvert et al., 2005; Hinrichs et al., 2000; Orphan et al., 2001a). The predominance of ANME-1 in the AOM zone of Tommeliten seeps is confirmed by 16S rDNA and FISH analysis. We found a very low diversity of archaeal $16 \mathrm{~S}$ rDNA clone sequences, which belonged almost entirely to the ANME-1b sub-cluster (98\% of the retrieved archaeal sequences, Table 2). Epifluorescence microscopy of CARDFISH targeted cells detected ANME-1 in the AOM zone (Fig. 10). In contrast, probes targeting ANME-2a, ANME$2 \mathrm{c}$ or ANME-3 gave no positive results in sediments from the AOM zone or around it.

Usually, ANME cells are found physically associated with SRB in samples from AOM zones of most seep systems. It is generally assumed that these SRB are syntrophic partners of ANME, however, so far, the mechanistic nature of their interaction remains unknown (Boetius et al., 2000; Hoehler et al., 1994; Nauhaus et al., 2002; Orphan et al., 2001b). Fingerprints of ${ }^{13} \mathrm{C}$-depleted bacterial FAs and microscopic observations using FISH showed, that the most common partners of ANME-1 and ANME-2 communities are SRB of the SeepSRB1 cluster (Blumenberg et al., 2004; Elvert et al., 2003; Knittel et al., 2003). Accordingly, the 16S rDNA clone library from sediments of the AOM zone contained high abundances of Seep-SRB1 sequences. Although sequences of the Seep-SRB1 in ANME-1 and ANME-2 dominated habitats form one cluster, FA lipid patterns suggest the existence of two distinct ecotypes of Seep-SRB1 with different FA fingerprints when associated to ANME-1 or ANME-2 (Blumenberg et al., 2004; Elvert et al., 2003). In the Tommeliten Aom zone, the high content of ai- $\mathrm{C}_{15: 0}$ relative to $\mathrm{i}-\mathrm{C}_{15: 0}$ and the lack of abundant amounts of $\mathrm{C}_{16: 1 \omega 5}$ suggest the presence of the Seep-SRB1 type associated to ANME-1 (Blumenberg et al. 2004).

\subsubsection{ANME-1/ANME-2 communities in MDACs}

Previous investigations showed that biomarker patterns in MDACs may be derived from living biomass or represent fossilized materials, or a mixture of both (Aloisi et al., 2002; Peckmann et al., 2002; Thiel et al., 2001). The presence of ${ }^{13} \mathrm{C}$-depleted archaeal lipids in subsurface and exposed MDACs indicate that carbonate precipitation at Tommeliten is associated with processes of seepage and AOM. The shapes of subsurface MDACs suggest that these were precipitated in pore spaces and channels formed by gas bubble streams. It is interesting to note that the subsurface and exposed MDACs contained different biomarker patterns. The subsurface MDACs were found to contain archaeal 
lipids, which indicate a mixed ANME-1/ANME-2 community. Compared to sediments of the AOM zone, the relative abundance of ANME-1 specific biphytanes was low (Fig. 7). The ratio of sn2-hydroxyarchaeol relative to archaeol was comparable to available values from settings comprising a mixed community consisting of ANME-1/ANME-2 or dominated by ANME-2 (Blumenberg et al., 2004; Elvert et al., 2005; Hinrichs et al., 1999, 2000; Orphan et al., 2001a). Diagnostic, archaeal lipids in ANME-2 dominated habitats were found to be more depleted in ${ }^{13} \mathrm{C}$ than those in ANME1 dominated habitats (Orphan et al., 2002). Hence, the lower $\delta^{13} \mathrm{C}$-values of archaeal lipids in the subsurface and exposed carbonates compared to the sediment $\left(\Delta \delta^{13} \mathrm{C}=\sim 25 \%\right.$, Fig. 7) further points to a higher contribution of ANME-2 to the archaeal biomass. In contrast to the subsurface MDACs, the MDACs exposed at the seafloor contained a biomarker signature typical for ANME-2 communities. Low amounts of biphytanes and high amounts of sn2-hydroxyarchaeol relative to archaeol (1:1.9, Fig. 7), substantial amounts of ${ }^{13} \mathrm{C}$ depleted crocetane (Fig. 8) as well as lower $\delta^{13} \mathrm{C}$-values of archaeal lipids in comparison to sediments of the AOM zone are in good agreement with published data for ANME-2 dominated systems (Blumenberg et al., 2004; Elvert et al., 2001, 2005, 1999; Orphan et al., 2001a, 2002). The subsurface as well as the exposed MDACs also contained lipid signatures typical of the Seep-SRB1 cluster commonly associated with ANME-1 or ANME-2. High amounts of ai- $\mathrm{C}_{15: 0}$ relative to $\mathrm{i}-\mathrm{C}_{15: 0}(2.1: 1$, Fig. 9) in subsurface MDACs are indicative of Seep-SRB1 associated with ANME-1, whereas in exposed MDACs, a ratio of nearly $1: 1$ and substantial amounts of $\mathrm{C}_{16: 1 \omega 5}$ point to the Seep-SRB1 ecotype associated to ANME-2 (Blumenberg et al., 2004; Elvert et al., 2003). It is possible that the MDACs found at Tommeliten preserve signatures of previous ANME- 2 communities once populating the surface sediments of this seep. At present, such a niche could exist in the reduced patches covered by bacterial mats, which we unfortunately were not able to sample because of their small size and patchy distribution. Previous studies at the cold seep systems of Hydrate Ridge showed a similar trend in the distribution of ANME-1 and ANME2 communities. Here, surface sediments are dominated by ANME-2 whereas the abundance of ANME- 1 was found to increase subsurface (Knittel et al., 2003, 2005). However, the environmental factors selecting for these different phylogenetic groups and their bacterial partner remain unknown.

\section{Conclusions}

So far, only very little is known on the identity, activity and distribution of AOM communities of shallow water cold seeps. In this investigation we revisited the Tommeliten area, a seepage site of the central North Sea. Here, an impermeable horizon of stiff marl sediments represents a natural barrier for methane rising from a deep gas reservoir. Methane pressure lifts this horizon forming dome-like subsurface structures. As a consequence, the marl may crack, allowing methane to advect into overlying, sediments of clay-silt. At the interface between silty and sandy sediments, methane is oxidised anaerobically by a community of ANME- 1 archaea and SRB of the Seep-SRB1 group in a defined subsurface horizon of ca. $20 \mathrm{~cm}$. This horizon also bears methane-derived authigenic carbonates and shows the highest AOM activity. AOM and SR rates are several orders of magnitude lower in comparison to AOM zones of highly active cold seeps. Nevertheless, the specific activity of methanotrophic cells detected in the sediments is comparable to AOM hot spots at cold seeps. All uprising methane is consumed within the sediments, except for a few locations with active gas venting to the hydrosphere. Here, at the crest of the marl domes, the ebullition of free gas circumvents microbial consumption most likely due to the presence of gas channels through sandy sediments. Thiotrophic bacterial mats as well as methane-derived authigenic carbonates exposed at the sea floor also indicate the presence of local gas escape routes.

Acknowledgements. This study was conducted as part of the METROL project (http://www.metrol.org) of the 5th framework program of the European Commission (EVK-3-CT-2002-00080). We thank captain, crew and shipboard scientists of R/V Heincke cruise HE-169 and HE-180 for their excellent support with work at sea. We thank G. Wendt and J. Wunderlich from Rostock University and Innomar Technologie $\mathrm{GmbH}$ for providing and operating the echosounder SES-2000. We thank W. Dimmler and R. Usbeck from FIELAX for ROV maintenance and operation, as well as support with mapping and geo-referencing, I. Busse, V. Beyer and T. Wilkop for laboratory analyses and G. Bening for handling the vibrocorer of the Institute for Baltic Sea Research (IOW). This study would not have been possible without the technical support by the Geology Department of the IOW. R. Rendle-Bühring, J. Schwarz and S. Steinke of the University Bremen are acknowledged for their help with sedimentological descriptions. We also thank T. Pape of the University Hamburg for the provision of analytical protocols.

Edited by: J. Middelburg

\section{References}

Aloisi, G., Bouloubassi I., Heijs S. K., Pancost R. D., Pierre C., Damste J. S. S., Gottschal J. C., Forney L. J., and Rouchy J. M.: $\mathrm{CH} 4$-consuming microorganisms and the formation of carbonate crusts at cold seeps, Earth and Planetary Science Letters, 203(1), 195-203, 2002.

Barry, J. P., Greene H. G., Orange D. L., Baxter C. H., Robison B. H., Kochevar R. E., Nybakken J. W., Reed D. L., and McHugh C. M.: Biologic and geologic characteristics of cold seeps in Monterey bay, California, Deep-Sea Research Part I, Oceanographic Research Papers, 43(11-12), 1739-1762, 1996.

Barry, J. P., Kochevar R. E., and Baxter C. H.: The influence of pore-water chemistry and physiology on the distribution of vesicomyid clams at cold seeps in Monterey Bay: Implications 
for patterns of chemosynthetic community organization, Limnol. Oceanogr., 42(2), 318-328, 1997.

Bian, L. Q., Hinrichs, K. U., Xie, T. M., Brassell, S. C., Iversen, H., Fossing, H., Jorgensen, B. B., and Hayes, J. M.: Algal and archaeal polyisoprenoids in a recent marine sediment: Molecular isotopic evidence for anaerobic oxidation of methane, Geochem. Geophys. Geosyst., 2 U1-U22, 2001.

Blumenberg, M., Seifert R., Reitner J., Pape T., and Michaelis W.: Membrane lipid patterns typify distinct anaerobic methanotrophic consortia, Proc. Natl. Acad. Sci. U. S. A., 101(30), 11 111-11 116, 2004.

Boetius, A., Ravenschlag, K., Schubert, C., Rickert, D., Widdel, F., Gieseke, A., Amann, R., Jørgensen, B. B., Witte U., and Pfannkuche O.: A marine microbial consortium apparently mediating anaerobic methane of oxidation, Nature, 407, 623-626, 2000.

Boetius, A. and Suess, E.: Hydrate Ridge: a natural laboratory for the study of microbial life fueled by methane from near-surface gas hydrates, Chemical Geology, 205(3-4), 291-310, 2004.

Bohrmann, G., Greinert, J., Suess, E., and Torres, M.: Authigenic carbonates from the Cascadia subduction zone and their relation to gas hydrate stability, Geology, 26(7), 647-650, 1998.

Bussmann, I., Dando, P. R., Niven, S. J., and Suess, E.: Groundwater seepage in the marine environment: role for mass flux and bacterial activity, Marine Ecology-Progress Series, 178, 169177, 1999.

Canfield, D., Kristensen, E., and Thamdrup, B.: Aquatic Geomicrobiology, Elsevier, 2005.

Çifçi, G., Dondurur, D., and Ergün, M.: Deep and shallow structures of large pockmarks in the Turkish shelf, Eastern Black Sea, Geo-Marine Lett., 23(3-4), 311-322, 2003.

Dando, P. R. and Hovland, M.: Environmental-Effects of Submarine Seeping Natural-Gas, Continental Shelf Research, 12(10), 1197-1207, 1992.

De Rosa, M. and Gambacorta, A.: The lipids of archaebacteria, Prog. Lipid Res., 27, 153-175, 1988.

Diaz-del-Rio, V., Somoza L., Martinez-Frias, J., Mata, M. P., Delgado, A., Hernandez-Molina, F. J., Lunar, R., MartinRubi, J. A., Maestro, A., Fernandez-Puga, M. C., Leon, R., Llave, E., Medialdea, T., and Vazquez, J. T.: Vast fields of hydrocarbon-derived carbonate chimneys related to the accretionary wedge/olistostrome of the Gulf of Cadiz, Marine Geology, 195(1-4), 177-200, 2003.

Elvert, M., Suess, E., and Whiticar, M. J.: Anaerobic methane oxidation associated with marine gas hydrates: superlight $\mathrm{C}$ isotopes from saturated and unsaturated $\mathrm{C}_{20}$ and $\mathrm{C}_{25}$ irregular isoprenoids, Naturwissenschaften, 86(6), 295-300, 1999.

Elvert, M., Greinert, J., Suess, E., and Whiticar, M. J.: Carbon isotopes of biomarkers derived from methane-oxidizing microbes at Hydrate Ridge, Cascadia convergent margin, in: Natural gas hydrates: Occurrence, distribution, and dynamics, vol. 124, edited by: Paull, C. K. and Dillon, W. P., American Geophysical Union, pp. 115-129, 2001.

Elvert, M., Boetius, A., Knittel, K., and Jorgensen, B. B.: Characterization of specific membrane fatty acids as chemotaxonomic markers for sulfate-reducing bacteria involved in anaerobic oxidation of methane, Geomicrobiol. J., 20(4), 403-419, 2003.

Elvert, M., Hopmans, E. C., Treude, D., Boetius, A., and Suess, E.: Spatial variatons of methanotrophic consortia at cold methane seeps: Implications from a high-resolution molecular and isotopic approach, Geobiology 3, in press, 2005.

Garcia-Garcia, A., Garcia-Gil, S., and Vilas, F.: Monitoring the Spanish gas fields in the Ria de Vigo (1991-2001), Geo-Marine Letters, 23(3-4), 200-206, 2003.

Henry, P., LePichon, X., Lallemant, S., Lance, S., Martin, J. B., Foucher, J. P., FialaMedioni, A., Rostek, F., Guilhaumou, N., Pranal, V., and Castrec, M.: Fluid flow in and around a mud volcano field seaward of the Barbados accretionary wedge: Results from Manon cruise, J. Geophys. Res.-Solid Earth, 101(B9), 20 297-20 323, 1996.

Hinrichs, K.-U. and Boetius, A.: The anaerobic oxidation of methane: New insights in microbial ecology and biogeochemistry, in: Ocean Margin Systems, edited by: Wefer, G., Billett, D., and Hebbeln, D., Springer-Verlag, Berlin, pp. 457-477, 2002.

Hinrichs, K.-U., Hayes, J. M., Sylva, S. P., Brewer, P. G., and DeLong, E. F.: Methane-consuming archaebacteria in marine sediments, Nature, 398, 802-805, 1999.

Hinrichs, K. U., Summons, R. E., Orphan, V., Sylva, S. P., and Hayes, J. M.: Molecular and isotopic analysis of anaerobic methane-oxidizing communities in marine sediments, Organic Geochemistry, 31(12), 1685-1701, 2000.

Hoehler, T. M. and Alperin, M. J.: Anaerobic methane oxidation by a methanogen-sulfate reducer consortium: geochemical evidence and biogeochemical considerations, in: Microbial Growth on $\mathrm{C}_{1}$ Compounds, edited by: Lidstrom, M. E. and Tabita, F. R., Kluwer Academic Publishers, pp. 326-333, 1996.

Hoehler, T. M., Alperin, M. J., Albert, D. B., and Martens, C. S.: Field and laboratory studies of methane oxidation in an anoxic marine sediment: Evidence for a methanogenic-sulfate reducer consortium, Global Biogeochem. Cycles, 8(4), 451-463, 1994.

Hovland, M.: On the self-sealing nature of marine seeps, Continental Shelf Research, 22(16), 2387-2394, 2002.

Hovland, M. and Judd, A. G.: Seabed Pockmarks and Seepages: Impact on Geology, Biology and the Marine Environment, Graham \& Trotman, 1988.

Hovland, M. and Sommerville, J. H.: Characteristics of two natural gas seepages in the North Sea, Marine and Petroleum Geology, 2(4), 319-326, 1985.

Hovland, M., Talbot, M., Olaussen, S., and Aasberg, L.: Recently formed methane-derived carbonates from the North Sea floor, in: Petroleum Geochemistry in Exploration of the Norwegian Shelf, edited by: Thomas, B. M., Norwegian Petroleum Soc., Graham \& Trotman, pp. 263-266, 1985.

Hovland, M., Talbot, M. R., Qvale, H., Olaussen, S., and Aasberg, L.: Methane-Related Carbonate Cements in Pockmarks of the North-Sea, J. Sedimentary Petrology, 57(5), 881-892, 1987.

Joye, S. B., Boetius, A., Orcutt, B. N., Montoya, J. P., Schulz, H N., Erickson, M. J., and Lugo, S. K.: The anaerobic oxidation of methane and sulfate reduction in sediments from Gulf of Mexico cold seeps, Chemical Geology, 205(3-4), 219-238, 2004.

Judd, A. G.: The global importance and context of methane escape from the seabed, Geo-Marine Lett., 23(3-4), 147-154, 2003.

Kane, M. D., Poulsen, L. K., and Stahl, D. A.: Monitoring the Enrichment and Isolation of Sulfate-Reducing Bacteria by Using Oligonucleotide Hybridization Probes Designed from Environmentally Derived 16s Ribosomal-Rna Sequences, Appl. Environ. Microbiol., 59(3), 682-686, 1993.

Knittel, K., Boetius, A., Lemke, A., Eilers, H., Lochte, K., 
Pfannkuche, O., Linke, P., and Amann, R.: Activity, distribution, and diversity of sulfate reducers and other bacteria in sediments above gas hydrate (Cascadia margin, Oregon), Geomicrobiol. J., 20(4), 269-294, 2003.

Knittel, K., Losekann, T., Boetius, A., Kort, R., and Amann, R.: Diversity and distribution of methanotrophic archaea at cold seeps, Appl. Environ. Microbiol., 71(1), 467-479, 2005.

Koga, Y., Nishihara, M., Morii, H., and Akagawa-Matsushita, M.: Ether polar lipids of methanogenic bacteria: Structures, comparative aspects, and biosyntheses, Microbiological Reviews, 57(1), 164-182, 1993.

Kohnen, M. E. L., Schouten, S., Sinninghé Damste, J. S., de Leeuw, J. W., Merritt, D. A., and Hayes, J. M.: Recognition of paleobiochemicals by a combined molecular sulfur and isotope geochemical approach, Science, 256, 358-362, 1992.

Lane, D. J., Pace, B., Olsen, G. J., Stahl, D. A., Sogin, M. L., and Pace, N. R.: Rapid-Determination of 16s Ribosomal-Rna Sequences for Phylogenetic Analyses, Proc. Natl. Acad. Sci. U. S. A., 82(20), 6955-6959, 1985.

Martin, J. B., Kastner, M., Henry, P., LePichon, X., and Lallement, S.: Chemical and isotopic evidence for sources of fluids in a mud volcano field seaward of the Barbados accretionary wedge, J. Geophys. Res.-Solid Earth, 101(B9), 20 325-20 345, 1996.

Massana, R., Murray, A. E., Preston, C. M., and DeLong, E. F.: Vertical distribution and phylogenetic characterization of marine planktonic Archaea in the Santa Barbara Channel, Appl. Environ. Microbiol., 63(1), 50-56, 1997.

Michaelis, W., Seifert, R., Nauhaus, K., Treude, T., Thiel, V., Blumenberg, M., Knittel, K., Gieseke, A., Peterknecht, K., Pape, T., Boetius, A., Amann, R., Jorgensen, B. B., Widdel, F., Peckmann, J. R., Pimenov, N. V., and Gulin, M. B.: Microbial reefs in the Black Sea fueled by anaerobic oxidation of methane, Science, 297(5583), 1013-1015, 2002.

Mills, H. J., Hodges, C., Wilson, K., MacDonald, I. R., and Sobecky, P. A.: Microbial diversity in sediments associated with surface-breaching gas hydrate mounds in the Gulf of Mexico, FEMS Microbiol. Ecol., 46(1), 39-52, 2003.

Moss, C. W. and Lambert-Fair, M. A.: Location of Double Bonds in Monounsaturated Fatty Acids of Campylobacter cryaerophila with Dimethyl Disulfide Derivatives and Combined Gas Chromatography-Mass Spectrometry, Journal of Clinical Microbiology, 27(7), 1467-1470, 1989.

Muyzer, G., Teske, A., Wirsen, C. O., and Jannasch, H. W.: Phylogenetic-Relationships of Thiomicrospira Species and Their Identification in Deep-Sea Hydrothermal Vent Samples by Denaturing Gradient Gel-Electrophoresis of 16s Rdna Fragments, Arch. Microbiol., 164(3), 165-172, 1995.

Nauhaus, K., Boetius, A., Kruger, M., and Widdel, F.: In vitro demonstration of anaerobic oxidation of methane coupled to sulphate reduction in sediment from a marine gas hydrate area, Environmental Microbiology, 4(5), 296-305, 2002.

Nauhaus, K., Treude, T., Boetius, A., and Kruger, M.: Environmental regulation of the anaerobic oxidation of methane: a comparison of ANME-I and ANME-II communities, Environmental Microbiology, 7(1), 98-106, 2005.

Nichols, P. D., Guckert, J. B., and White, D. C.: Determination of monounsaturated fatty acid double-bond position and geometry for microbial monocultures and complex consortia by capillary GC-MS of their dimethyl disulphide adducts, J. Microbiol.
Methods, 5, 49-55, 1986.

Orphan, V. J., Hinrichs, K. U., Ussler, W., Paull, C. K., Taylor, L. T., Sylva, S. P., Hayes, J. M., and Delong, E. F.: Comparative analysis of methane-oxidizing archaea and sulfate-reducing bacteria in anoxic marine sediments, Appl. Environ. Microbiol., 67(4), 1922-1934, 2001a.

Orphan, V. J., House, C. H., Hinrichs, K. U., McKeegan, K. D., and DeLong, E. F.: Methane-consuming archaea revealed by directly coupled isotopic and phylogenetic analysis, Science, 293(5529), 484-487, 2001b.

Orphan, V. J., House, C. H., Hinrichs, K. U., McKeegan, K. D., and DeLong, E. F.: Multiple archaeal groups mediate methane oxidation in anoxic cold seep sediments, Proc. Natl. Acad. Sci. U. S. A., 99(11), 7663-7668, 2002.

Orphan, V. J., Ussler, W., Naehr, T. H., House, C. H., Hinrichs, K. U., and Paull, C. K.: Geological, geochemical, and microbiological heterogeneity of the seafloor around methane vents in the Eel River Basin, offshore California, Chemical Geology, 205(3-4), 265-289, 2004.

Peckmann, J., Goedert, J. L., Thiel, V., Michaelis, W., and Reitner, J.: A comprehensive approach to the study of methane-seep deposits from the Lincoln Creek Formation, western Washington State, USA, Sedimentology, 49(4), 855-873, 2002.

Peckmann, J., Paul, J., and Thiel, V.: Bacterially mediated formation of diagenetic aragonite and native sulfur in Zechstein carbonates (Upper Permian, Central Germany), Sedimentary Geology, 126(1-4), 205-222, 1999.

Pernthaler, A., Preston, C. M., Pernthaler, J., DeLong, E. F., and Amann, R.: Comparison of fluorescently labeled oligonucleotide and polynucleotide probes for the detection of pelagic marine bacteria and archaea, Appl. Environ. Microbiol., 68(2), 661-667, 2002.

Ravenschlag, K., Sahm, K., Pernthaler, J., and Amann, R.: High bacterial diversity in permanently cold marine sediments, Appl. Environ. Microbiol., 65(9), 3982-3989, 1999.

Reeburgh, W. S.: "Soft spots" in the global methane budget, in: Microbial Growth on $\mathrm{C}_{1}$ Compounds, edited by: Lidstrom, M. E. and Tabita, F. R., Kluwer Academic Publishers, pp. 334-342, 1996.

Roberts, H. H. and Aharon, P.: Hydrocarbon-Derived Carbonate Buildups of the Northern Gulf-of-Mexico Continental-Slope - a Review of Submersible Investigations, Geo-Marine Lett., 14(23), 135-148, 1994.

Schouten, S., Hoefs, M. J. L., Koopmans, M. P., Bosch, H.-J., and Sinninghe Damsté, J. S.: Structural characterization, occurrence and fate of archael ether-bound acyclic and cyclic biphytanes and corresponding diols in sediments, Organic Geochemistry, 29(57), 1305-1319, 1998.

Schouten, S., Hopmans, E. C., Schefuss, E., and Damste, J. S. S.: Distributional variations in marine crenarchaeotal membrane lipids: a new tool for reconstructing ancient sea water temperatures?, Earth and Planetary Science Lett., 204(1-2), 265-274, 2002.

Teske, A., Hinrichs, K. U., Edgcomb, V., Gomez, A. D., Kysela, D., Sylva, S. P., Sogin, M. L., and Jannasch, H. W.: Microbial diversity of hydrothermal sediments in the Guaymas Basin: Evidence for anaerobic methanotrophic communities, Appl. Environ. Microbiol., 68(4), 1994-2007, 2002.

Tryon, M. D., Brown, K. M., Torres, M. E., Trehu, A. M., Mc- 
Manus, J., and Collier, R. W.: Measurements of transience and downward fluid flow near episodic methane gas vents, Hydrate Ridge, Cascadia, Geology, 27(12), 1075-1078, 1999.

Thiel, V., Peckmann, J., Richnow, H. H., Luth, U., Reitner, J., and Michaelis, W.: Molecular signals for anaerobic methane oxidation in Black Sea seep carbonates and a microbial mat, Mar. Chem., 73(2), 97-112, 2001.

Thomsen, T. R., Finster, K., and Ramsing, N. B.: Biogeochemical and molecular signatures of anaerobic methane oxidation in a marine sediment, Appl. Environ. Microbiol., 67(4), 1646-1656, 2001.

Thrasher, J., Fleet, S. J., Hovland, M., and Düppenbecker, S.: Understanding geology as the key to using seepage in exploration: spectrum of seepage styles, in: Hydrocarbon migration and its near-surface expression, edited by: Schumacher, D. and Abrams, M. A., AAPG Memoir, pp. 223-241, 1996.
Treude, T., Boetius, A., Knittel, K., Wallmann, K., and Jorgensen, B. B.: Anaerobic oxidation of methane above gas hydrates at Hydrate Ridge, NE Pacific Ocean, Marine Ecology-Progress Series, 264 1-14, 2003.

Treude, T., Niggemann, J., Kallmeyer, J., Wintersteller, P., Schubert, C. J., Boetius, A., and Jorgensen, B. B.: Anaerobic oxidation of methane and sulfate reduction along the Chilean continental margin, Geochimica et Cosmochimica Acta, 69(11), 27672779, 2005.

Widdel, F. and Bak, F.: The gram negative mesophilic sulfate reducing bacteria, in: The prokaryotes, edited by: Dworkin, M., Springer, 3352-3378, 1992. 